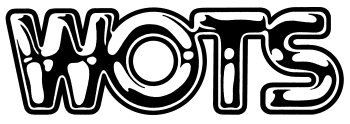

\title{
Gridded Surface Subsurface Hydrologic Analysis (GSSHA) Model Simulation of Hydrologic Conditions and Restoration Scenarios for the Judicial Ditch 31 Watershed, Minnesota
}

by Charles W. Downer, William F. James, Aaron Byrd, and Gregory W. Eggers

PURPOSE: The purpose of this demonstration was to simulate the hydrology of a small, extensively ditched and tiled agricultural watershed located in western Minnesota (Judicial Ditch 31) using the physically based, multi-dimensional watershed hydrology model: Gridded Surface Subsurface Hydrologic Analysis Model (GSSHA). The original GSSHA model, which solves a one-dimensional form of the Richard's Equation to estimate groundwater recharge, was modified to allow a simplified infiltration/soil moisture accounting routine (Green and Ampt with Redistribution) to provide recharge values. The modified model was then applied to the Judicial Ditch (JD31) watershed in an effort to simulate both surface water runoff and subsurface (i.e., primarily tile drainage) flow. The location of the network of tile drains was determined by modeling the basin with only the ditches, and defining ponded areas in the watershed as regions drained by subsurface tiles, since no water currently ponds in the watershed. These tile drainage areas were then simulated by (a) modeling them as highly porous soils to simulate the present lake ponding on land surface (Model 1), and (b) modeling the tile drains as a network of small, rough channel sections (Model 2). These two models were calibrated against observed data for the period of June through July 2000. Both models were capable of representing smaller events and baseflow. Model 2 provided better representations of larger events, especially the storm volumes. Model 1 was used to estimate the effects of wetland restoration on surface ponding for wet, dry, and normal rainfall using the June-July period. The tile drainage areas were divided into four regions within the watershed and the effects of restoring 25, 50, 75, and 100 percent of the original wetland areas on surface ponding were examined. These simulations showed that wetlands could be created by removing the tile drains from selected regions in the watershed, thereby buffering hydrologic runoff events to JD31.

BACKGROUND: The JD31 watershed is a small, highly disturbed watershed located in an important agricultural production area in southwestern Minnesota. Drained with a uniform ditch and an extensive tile network, this small watershed is representative of agricultural and drainage practices in the region. It is believed that the use of fertilizers in this and similar regions results in high nitrogen and phosphorous loadings to the Mississippi River. Carried downstream during spring floods, these nutrients are swept into the Gulf of Mexico, resulting in the rapid growth of algae. These algae later die, sink, and begin to decay, causing a heavy oxygen demand in the water. Confined by summer stratification, this oxygen demand results in very low levels of dissolved oxygen near the seafloor. The depletion of oxygen results in the death or displacement of marine life within the zone of decay. Media reports indicate that for the summer of 2001 this zone covered more than 8,000 square miles (Vicksburg Post 2001). 
It may be possible to reduce nutrient-related water quality problems through the restoration of highly disturbed watersheds such as JD31. Restoration efforts and best management practices (BMPs) should be aimed at reducing peak flows and storm volumes. By retaining and/or delaying storm flows, sediment and nutrient loadings can also be reduced. Restoration practices include wetland restoration, buffer strips, no-till farming, channel restoration, and reestablishment of riparian areas.

While restoration attempts may provide significant return, they can be costly to implement and often are met with resistance in agricultural communities. In order to quantify potential benefits, detailed hydrologic modeling of watersheds and effects of BMPs on hydrology and loadings is required. Extending model results beyond the range of calibration to model future conditions, such as implementation of BMPs, requires the use of physically based hydrologic models that simulate the processes that generate stream flow. It was proposed that the physically based hydrologic model GSSHA (Downer and Ogden, in preparation) be used to investigate the current hydrologic response of the JD31 watershed under ditched and tiled conditions. The GSSHA model was then modified to simulate wetland restoration by reducing tile drainage in regions of the watershed in order to evaluate the potential for hydrologic retention.

When applying a physically based model, knowledge of the material properties of the watershed is of vital importance. These watershed properties determine which physical processes will dominate stream flow. These physical conditions include relief, overland flow roughness, the type and composition of the soil, vegetation, and the spatial and temporal variation of rainfall and other hydro-meteorological conditions. A key to a successful modeling effort was the effective simulation of the tile drainage network. The ability to correctly simulate current conditions depended heavily on the scheme used to simulate the ditch and drainage network.

In this report, the physical properties of the JD31 watershed will first be described. Next, the GSSHA model, modifications to the model, and model parameters used to simulate the JD31 watershed will be presented. Two methods used to simulate the tile drainage system will be discussed. This discussion is followed by a description and results of different restoration alternatives analyzed with the model. Finally, concluding remarks summarize the results of the study.

STUDY SITE: The Coon Creek/JD31 watershed covers $23.3 \mathrm{~km}^{2}$, and spans two counties in Minnesota - Lyon and Lincoln Counties. The watershed is located in an agricultural area in the

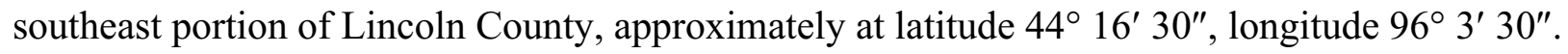
Location of the watershed is shown in Figure 1. The JD31 system, representing a substantial portion of the Coon Creek watershed (Figure 2), was created in 1916 to drain the many wetland pockets in the area, making it suitable for agriculture. JD31 eventually drains to the Redwood River. Before being modified to accommodate agriculture, the watershed drained by JD31 was a prairie region pock-marked by seasonal pothole (dead-end) wetlands. Coon Creek cut through the watershed, and provided marginal drainage with the stream network depicted by Figure 3. As shown in Figure 3, the JD31 watershed was originally not a single watershed, but several smaller watersheds that drained in various directions.

Drainage. The JD31 hydrology was drastically altered to allow for more complete drainage of the watershed. The natural stream network, as shown in Figure 3, was replaced by a large incised 


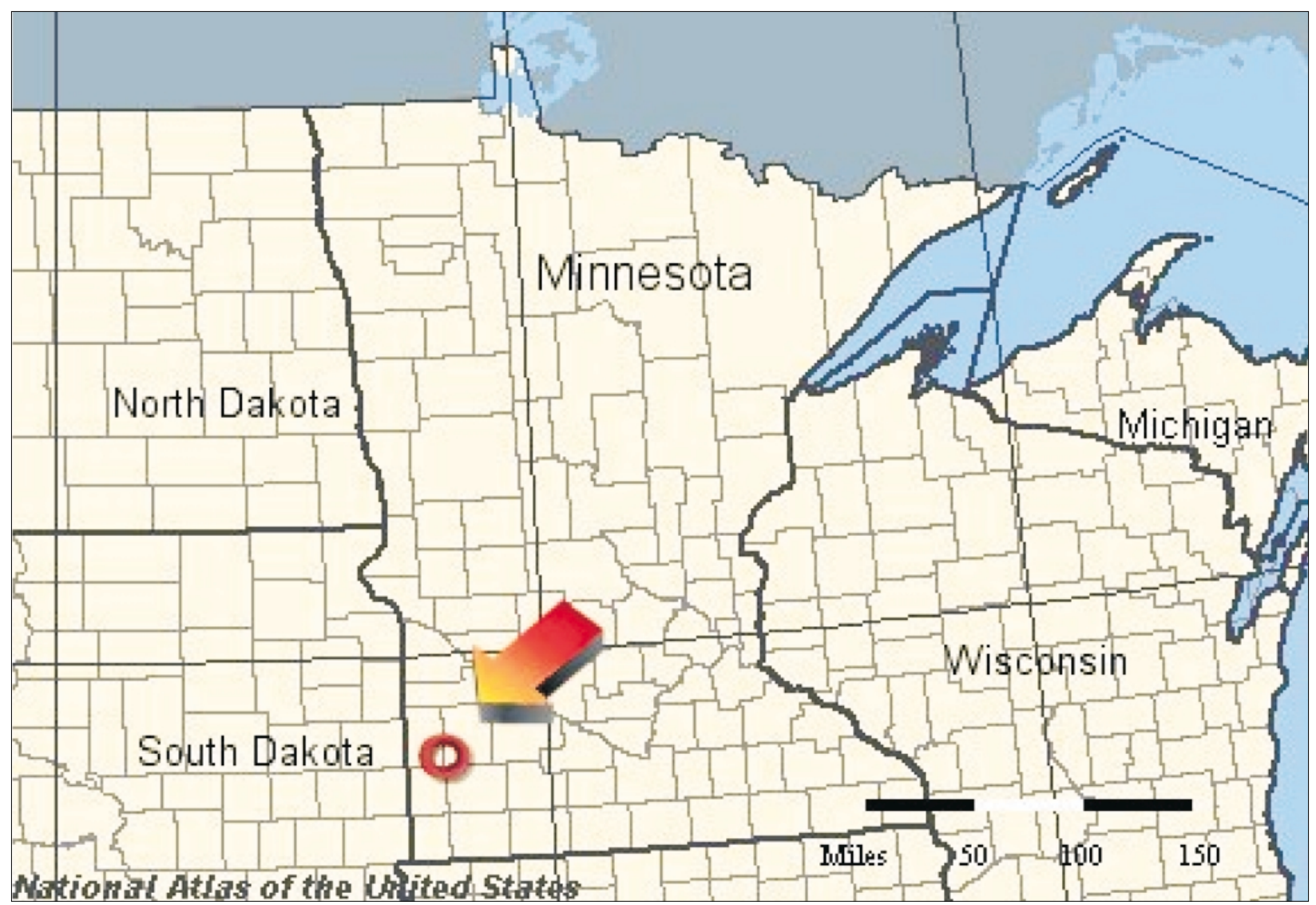

Figure1. Location of the Judicial Ditch 31 watershed (National Atlas of the United States of America 2001)

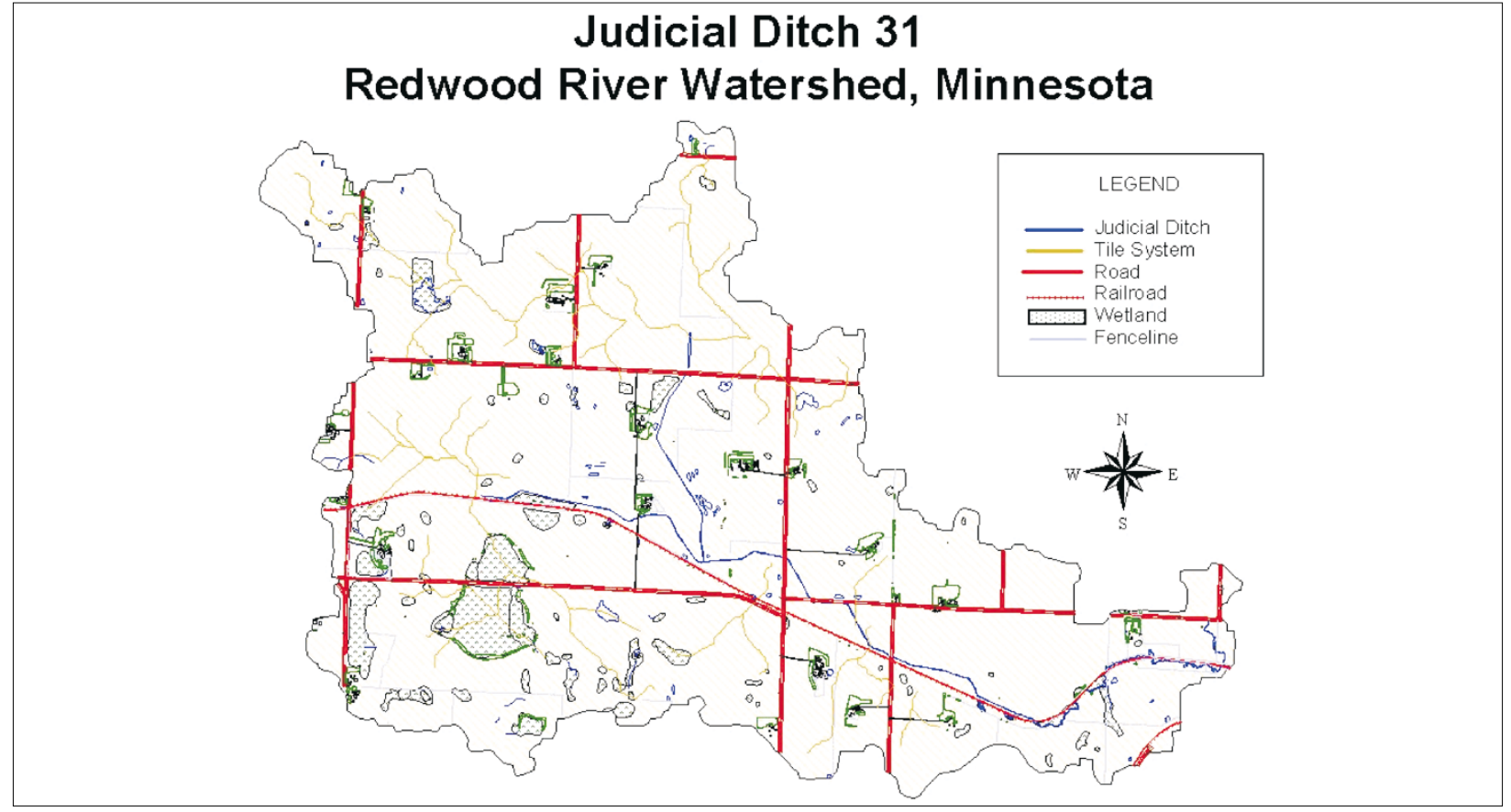

Figure 2. Map of the Judicial Ditch 31 (JD31) watershed showing ditches, tile systems, roads, railroads, wetlands, fence lines, and sampling station location. Note that JD31 is part of the Coon Creek watershed system. Cook Creek enters the watershed from the northeast 


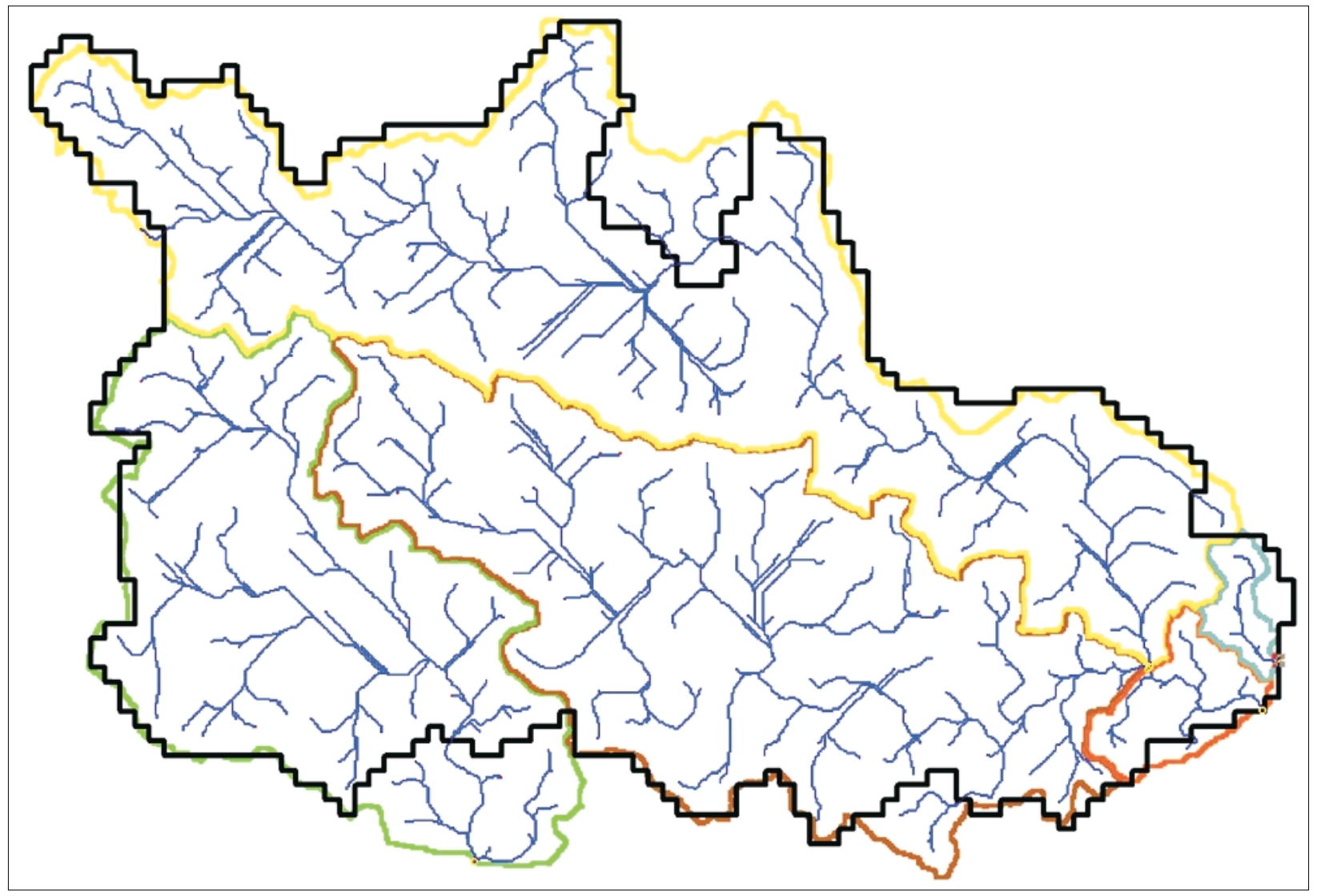

Figure 3. Natural drainage system of the Coon Creek/Judicial Ditch 31 watershed. Natural sub-watersheds are outlined in various colors

uniform ditch that traverses the watershed, as shown in Figure 2. While roughly following the natural drainage, the ditch system also cuts through both hills and valleys to more efficiently move water out of the watershed, thereby altering certain aspects of the natural drainage system. Currently, a complex system of tile drains moves the water from the many low dead-end potholes to the ditch. These tiles range in size up to a foot in diameter, and drain the previously wetland areas with standpipes. The larger tile drains depicted in Figure 2 are thought to roughly follow the natural drainage patterns shown in Figure 3. The watershed currently encompasses over $11 \mathrm{~km}$ of open ditch and $31 \mathrm{~km}$ of subsurface drainage tile (Paulson and Philippi 1998).

The drainage network described above is very effective at removing water from the basin, and very little, if any, water remains ponded on the watershed surface after the end of a rainfall event. Due to extensive tiling, only about $0.2 \mathrm{~km}^{2}$ of the watershed remain as natural wetland areas versus over $3 \mathrm{~km}^{2}$ of natural wetlands prior to tiling and ditching (Paulson and Philippi 1998). The fact that the watershed is nearly 100-percent agricultural attests to the efficiency of the tile drainage system. Flow data collected at the site for the year 2000 (Figure 4) show that the watershed response to rainfall appears as a basin receiving mixed hydrologic inputs from surface and groundwater sources. The surface water provides the fast response (spikes) and groundwater provides the long tails and extended base flow. The actual response is more complicated, involving direct runoff into the ditch, groundwater recharge to the ditch, and water from a series of tile drains emptying into the ditch. 


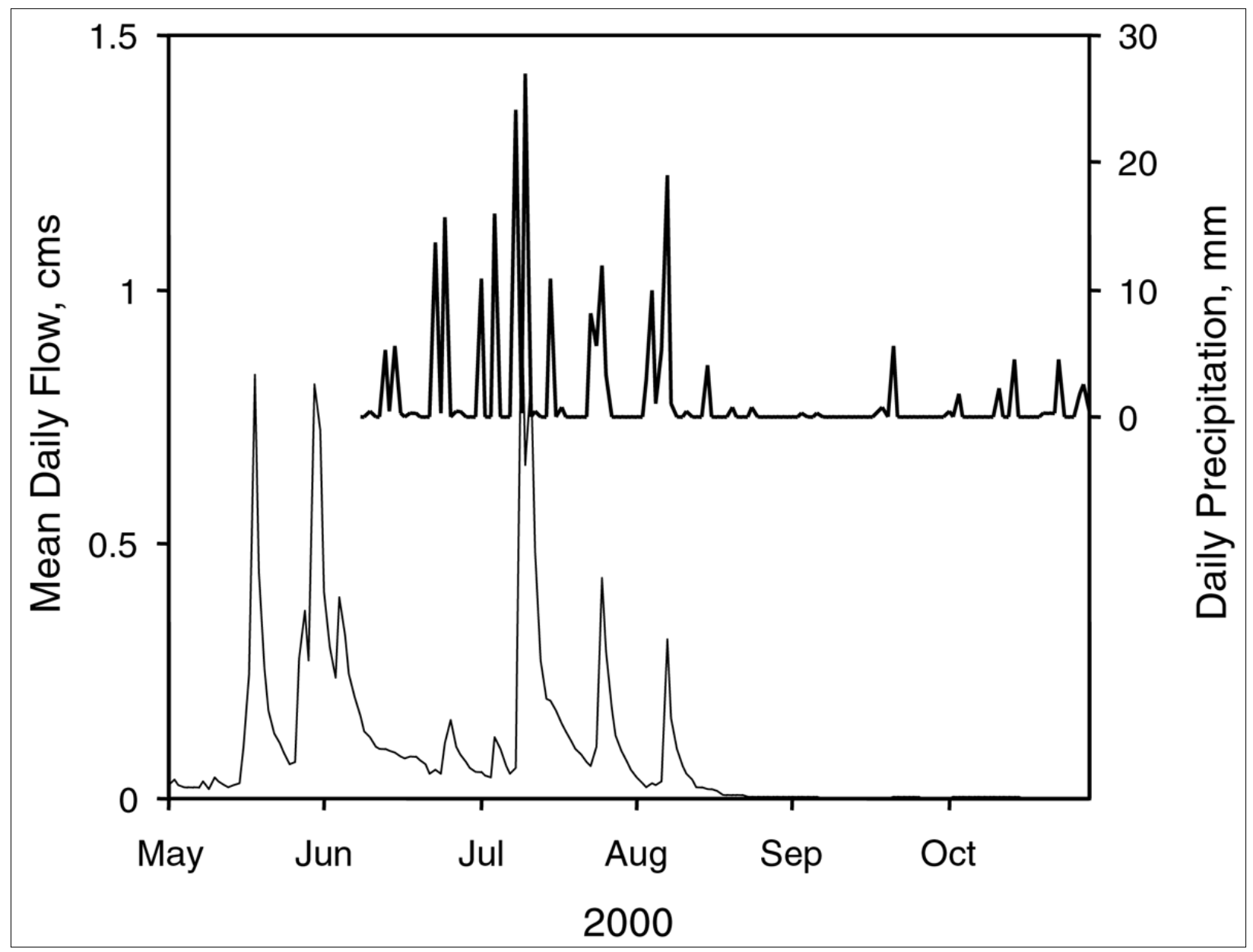

Figure 4. Seasonal variations in mean daily flow (black line) and daily precipitation (grey line) from the Judicial Ditch watershed in 2000

Geology. The land surface of the watershed ranges from 500 to $526 \mathrm{~m} \mathrm{NGVD.} \mathrm{The} \mathrm{digital} \mathrm{eleva-}$ tions are shown in Figure 5. The bedrock in the Coon Creek area is either a Pre-Cambrian granite or Pre-Cambrian quartzite. The elevation of the bedrock ranges from approximately 354 to 378 $\mathrm{m}$ and slopes towards the southeast. There are five sequences of Pleistocene glacial till deposits. Each sequence shows an unoxidized till capped with a layer of oxidized till. The sequences of till deposits are of variable thicknesses, from 15 to $45 \mathrm{~m}$ (Rodis 1963). The surface is very hummocky, typical of glacial terrain. Due to the hummocky terrain, many areas of the watershed were originally wetlands.

Soils. Soil surveys (Hokanson 1970, 1975) show more than 20 soil classifications in the area, most of which are either a silty loam or a silty clay loam. The general classified soil type of the area is a Barnes-Flom-Buse soil. The Barnes-Flom-Buse is a clayey, silty loam. Approximately 5 percent of the area is considered sandy. The sandy areas are distributed fairly uniformly throughout the watershed. More detailed information on the soils can be found in Appendix A.

Land Use. Row crop agriculture is the predominate land use in the watershed (Figure 2). Soybeans and corn are the primary crops. Several farm homesteads dot the landscape but do not 


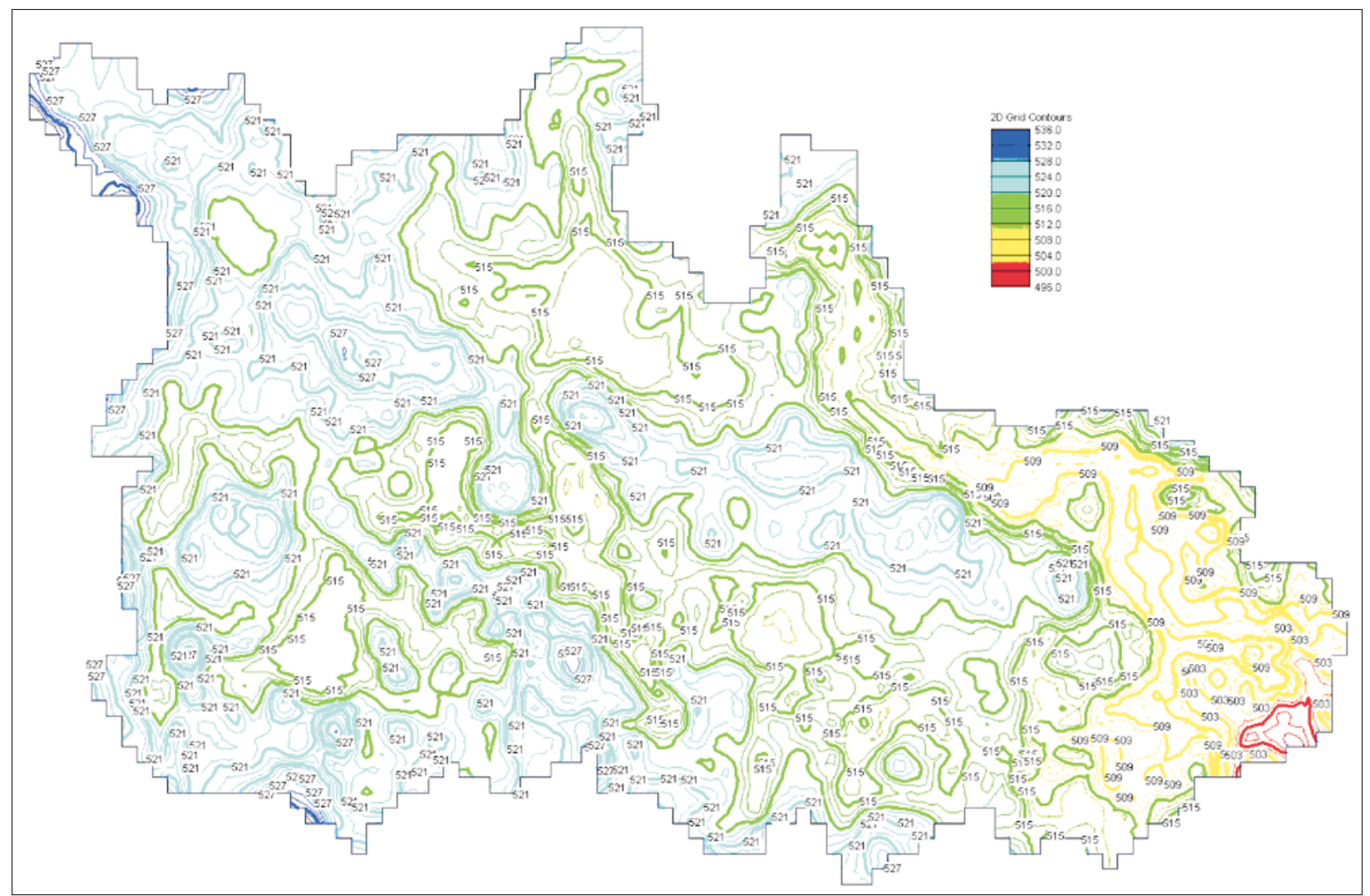

Figure 5. Digital elevations of Judicial Ditch watershed

comprise a significant portion of the watershed. In addition, a very narrow riparian area, on the order of $50 \mathrm{~m}$, exists along JD31.

Climate. According to the soil survey (Hokanson et al. 1970), Lyon County has a cool climate, typical of areas at that latitude. The daily mean summer temperature is $21.3{ }^{\circ} \mathrm{C}$, and that of winter is $-9.2^{\circ} \mathrm{C}$. Annual amount of precipitation is $617 \mathrm{~mm}$, with " 75 percent usually falling in April through September” (Hokanson 1978, Hokanson et al. 1970).

The National Climatic Data Center (NCDC) (2001) reported that the lower portion of Lyon County received $681 \mathrm{~mm}$ of precipitation in the 2000 calendar year. The maximum daily precipitation occurred in May, with $64 \mathrm{~mm}$ of rainfall recorded in one 24-hr period. Also, during June and July the mean maximum daily temperatures were $24.8^{\circ} \mathrm{C}$ and $26.9^{\circ} \mathrm{C}$, respectively (NCDC 2001).

\section{METHODS}

Monitoring. In May 2000, a flow gauging and precipitation sampling station was established in a box culvert ( $8 \mathrm{ft}$ by $8 \mathrm{ft}$ ) under State Highway 23, located near the mouth of the ditch before it enters the Redwood River (Figure 2). Instantaneous velocity and stage height were measured at 15-min intervals (between May and November) using an ISCO 4150 area-velocity sensor (ISCO, Inc; Lincoln, NE). These data were converted to flow (cubic meters per second, cms) using the software program FlowLink 4 (ISCO, Inc.). Precipitation was measured over 15-min intervals 
using an ISCO 674 precipitation logger (ISCO, Inc.). Recorded flows and rainfall are shown in Figure 4. See James et al. (2001) for further information regarding flow and constituent loading from the JD31 watershed.

Modeling Modifications. Previous attempts to simulate flows in similar watersheds in this region (i.e., nearby Clear Creek watershed) using a purely Hortonian model, CASC2D (Ogden 1998) have produced disappointing results (Jorgeson 2000). While the CASC2D model was able to simulate the fast watershed response, in part, the model grossly underestimated the volume of flow for events. The CASC2D model could not reproduce the general hydrograph shape because the model has no mechanisms to simulate the processes involved in creating base flow or the long tails on the hydrographs as seen in Figure 4.

In an attempt to model this complex and poorly described hydrologic system, the GSSHA (Downer and Ogden, in preparation) hydrologic model was modified and then used to simulate the watershed response. It was hoped that the GSSHA model, which allowed for both surface water and subsurface water calculations and interactions, could provide better reproductions of observed flows and could be used to simulate the effects of wetland restoration in the watershed.

The GSSHA model is a developmental model created in the Coastal and Hydraulics Laboratory (CHL) of the Engineer Research and Development Center (ERDC), in collaboration with Professor Fred Ogden, University of Connecticut. The GSSHA model is a reformulation and enhancement of the Hortonian hydrologic model CASC2D. Like CASC2D, GSSHA is a physically based, distributed parameter, multi-dimensional hydrologic model. Major advancements for GSSHA include:

- More streamlined, modular formulation.

- Process-based, with each process having its own time-step and internal time-step limitations for stability.

- Improved overland flow and channel routing algorithms that allow a larger overall time-step and simulation of backwater effects.

- 1-D unsaturated zone modeling with Richard's Equation (RE) allows integrated estimation of infiltration, evapo-transpiration (ET), groundwater recharge, and soil moisture profiles.

- 2-D saturated lateral groundwater flow allows the calculation of groundwater movement and its effect on stream flow and soil moistures.

- Stream/groundwater interaction allows calculation of base flow.

- Exfiltration/groundwater recharge - allows overland flow plane/groundwater interaction.

In the GSSHA model, the RE can be used to simulate the unsaturated zone and link the overland flow plane to saturated groundwater. The solution of RE provides detailed information on soil moistures, infiltration, ET, and groundwater recharge. For this study simpler methods available in the model to calculate infiltration, ET, and soil moisture, were linked to the saturated groundwater flow model to allow a less rigorous method to make calculations in the unsaturated zone. The saturated groundwater flow was linked to the Green and Ampt with redistribution (GAR; Ogden and Saghafian 1997) to the 2-D saturated groundwater flow calculations. In addition to using the GAR method, the simple "bucket" soil moisture accounting routine was used to 
calculate soil moistures between rainfall events using the Penman-Montieth method to calculate ET demand (Senarath et al. 2000).

These modifications made it possible to roughly simulate groundwater/surface water interaction, without solving the highly nonlinear RE. This was advantageous because the solution was easy, fast, and could be used to quickly analyze watersheds. This approach was thought to be appropriate for this basin because the many unknown variables, such as information of sub-surface parameters, groundwater elevations, and the location, type and functioning of the tile drains, already precluded an extremely accurate analysis. Also, the primary purpose of the model was to have the ability to semi-quantitatively analyze the effects of management/restoration decisions.

GAR, as described by Ogden and Saghafian (1997), calculates infiltration and soil moisture based on the movement of multiple sharp wetting fronts that occur with rainfall burst followed by rainfall hiatus. The GSSHA model was modified so that the infiltration calculated by GAR was used as groundwater recharge to the 2-D saturated groundwater flow. In order to make this link, the overall code was modified, as well as the GAR code, the 2-D saturated flow code, and the exfiltration routines.

Changes to the overall code. Overall, GSSHA was modified so that the long-term simulation using the GAR method was integrated with the subsurface calculations in a format similar to that used for the RE solution. The following differences/changes are noted.

- The groundwater recharge for each time-step is equal to the infiltration computed by GAR. In the model, the groundwater recharge is computed for each time-step as:

$$
\begin{aligned}
\text { recharge } & =\left(\text { infil }^{t+\Delta t}-\right.\text { infil } \\
\text { infil } & =\text { infiltration } \\
t & =\text { current time level area } \text { where: } \\
\Delta t & =\text { time step } \\
t+\Delta t & =\text { next time level }
\end{aligned}
$$

- Overland depths are initialized at the beginning of the simulation only, and are not zeroed at the beginning or end of rainfall events. Water remaining on the water surface at the end of a rainfall event continues to flow across the overland plane and infiltrate, providing groundwater recharge during non-event periods.

As in the original formulation, soil moisture accounting begins at the designated end of the rainfall event. At that time the soil moistures provided by the GAR method are sent to the soil moisture accounting routine and soil moisture calculations proceed until the next specified rainfall event. In the soil moisture accounting routine, the soil moisture is adjusted hourly for losses due to ET only. Even though water may be present on the overland flow plane, flowing and infiltrating, this does not affect the soil moisture accounting calculations. In this respect there is a disconnection between the ET calculations and the infiltration calculations.

Exfiltration. As described in the GSSHA User's Manual (Downer and Ogden, in preparation), when the groundwater elevations exceed the ground surface elevation, infiltration calculations for the cell cease, and the groundwater surface exchange is calculated in the exfiltration routine in the following manner: 
- If the groundwater elevation is greater than the combined value of the elevation of the cell and the overland flow depth, the flux onto the overland flow plane is computed for each infiltration time-step as:

exfiltration $=\left(\right.$ elev $_{g w}-($ elev $\left.+h)\right) \frac{\mathrm{D} t_{\text {inf }}}{\mathrm{D} t_{g w}} S$

where: elev is the elevation in the cell, $e l e v_{g w}$ is the elevation of the groundwater surface, $h$ is the depth of water in the cell, $\Delta t_{i n f}$ is the infiltration time step, $\Delta t_{g w}$ is the groundwater time step, and $S$ is the storage in the cell, as defined below.

- If the groundwater elevation is less than the combined value of the elevation of the cell and the overland flow depth, the flux is into the groundwater and the exfiltration is calculated each infiltration time-step as recharge $=$ leakage $_{g w} \mathrm{D}_{\text {inf }}$

where: leakage $e_{g w}$ is the leakage through the lower boundary of the structured groundwater.

The depth of water on the overland flow plane is adjusted according to the calculated exfiltration. If the calculated groundwater recharge is greater than the depth of water on the overland flow plane, then the recharge is set to the overland flow depth of the cell.

Any time exfiltration occurs, the infiltration and overland flow processes are started if they are not already active. The processes remain active as long as exfiltration occurs and until all water on the overland flow plane stops moving and infiltrating.

Modifications to the GAR model. The GAR code was modified to allow infiltration to occur before the first rainfall event (in the case of exfiltration), and to continue to occur after flow in the channel drops below the EVENT_MIN_Q (Ogden 1998), as specified by the user. Additionally, the GAR model was modified such that infiltration is not calculated for cells in which exfiltration is occurring.

Modifications to the groundwater model. The groundwater model was modified in order to allow the GSSHA model to work with the simplified recharge calculations. The recharge to the groundwater model is calculated from the GAR infiltration routine. The storage term used in each cell is assumed to be the porosity of the cell minus the initial moisture term. The initial moisture term is updated at the beginning of each rainfall event.

JD31 Watershed Modeling Approach. The GSSHA model inputs were created using the Watershed Modeling System (WMS) Version 6.1 (Nelson 2001), which is completely integrated with the GSSHA model Version 1.37a.

Grid establishment. The GSSHA model is based on finite difference/finite volume methods and a computational grid was used to represent the watershed. The JD31 watershed was modeled with an $86 \times 57$ grid with uniform cells of $90 \mathrm{~m}$ on each face. There were 2,870 active cells in the watershed (Figure 6). This grid was extended beyond the JD31 watershed (Figure 2) limits in order to obtain a better groundwater boundary. The $90-\mathrm{m}$ grid was created by aggregating 10X10m topology data from USGS digital elevation maps (DEM's). 


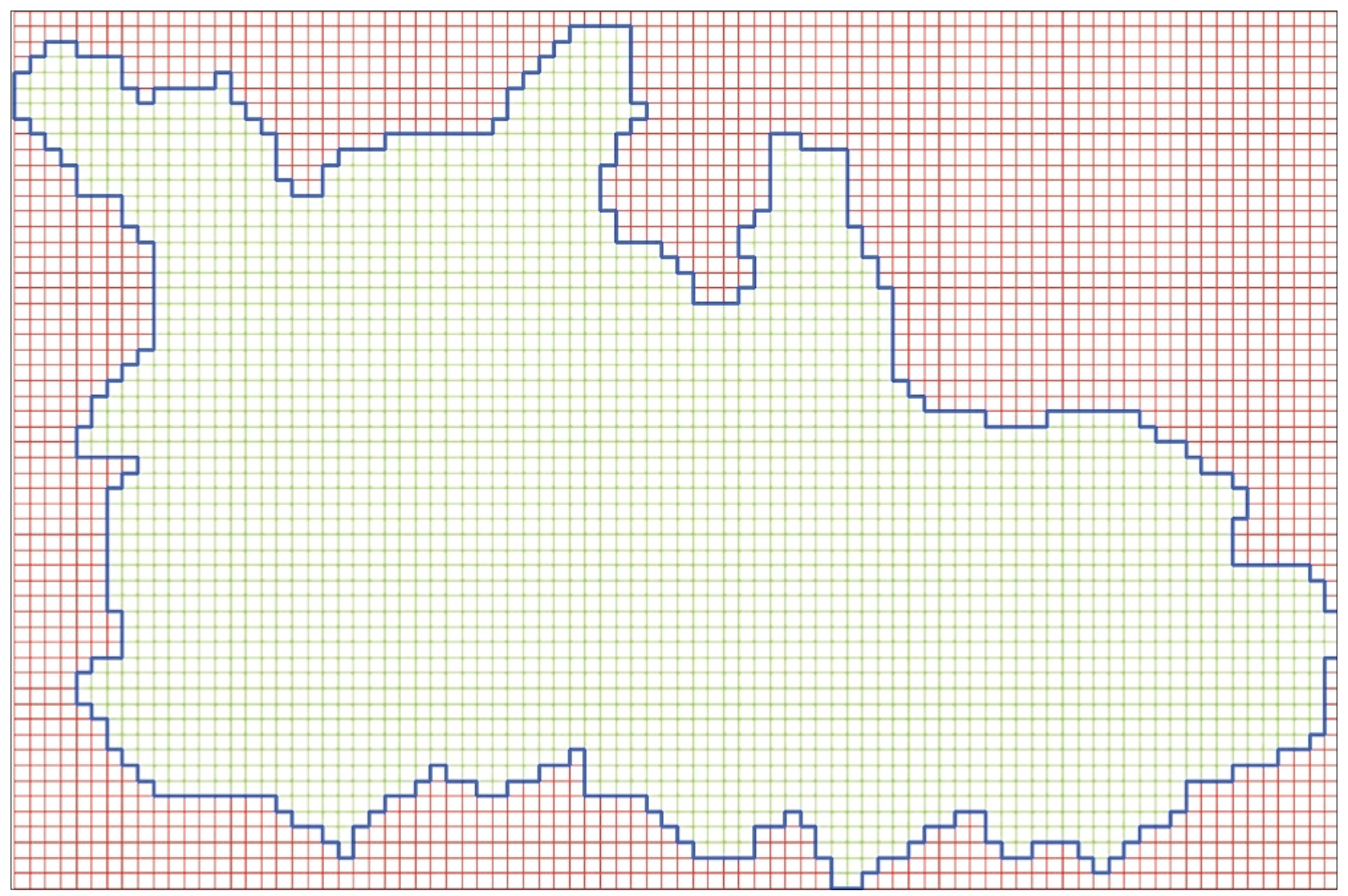

Figure 6 . The 86 by 57 computational grid for the Judicial Ditch 31 watershed

Process identification. GSSHA is a process-based model, and a complete GSSHA model is created by selecting processes to be modeled along with an applicable solution. The following processes and methods were used:

- 2-D overland flow with diffusive wave equation.

- 1-D channel flow with diffusive wave equation, normal flow outlet boundary.

- Stream base flow.

- Infiltration using Green and Ampt with Redistribution (GAR).

- Evapo-transpiration using the Penman-Montieth method.

- Soil moisture accounting using the bucket method.

- Groundwater recharge - GAR method.

- 2-D lateral groundwater flow.

Simulating the tile drainage network. A major hydrologic component of the JD31 watershed is the extensive tile drainage network. However, the GSSHA model contains no specific tile drain modeling options. In addition, the exact type and location of the tile drains are largely unknown. In this study, the GSSHA model was applied in an attempt to simulate the watershed response including the tile drains, as opposed to actually simulating the tiles themselves.

The tile drains were located by simulating the overland flow plane assuming uniform conditions in the watershed and determining where water ponds on the surface. For this simulation, the soil in the watershed was assumed to be clay loam with GAR infiltration parameters taken from 
Rawls, Brakensiek, and Miller (1983). Overland flow, channel flow, and infiltration processes were simulated. A $25-\mathrm{mm} / \mathrm{hr}$ uniform rainfall was applied over the watershed for $2 \mathrm{hr}$, resulting in $50 \mathrm{~mm}$ of rainfall falling on the basin. At the end of the rainfall event, areas that had ponded water were outlined. The locations of these cells are shown in Figure 7. As no water is thought to remain ponded on the watershed at the end of rainfall events, it was thought that these cells are tile-drained. The tile-drained areas represent approximately 28 percent of the watershed.

Model 1 Representation. One method of representing the tiles was to mimic the effect of the tiles by adjusting the hydraulic conductivity of the tile-drained cells and of the uniform groundwater hydraulic conductivity used in the basin. Increasing the hydraulic conductivity of the tile drain cells causes water to infiltrate instead of ponding. Increasing the uniform groundwater hydraulic conductivity increases the rate at which water can move from the tile-drained cells into the subsurface media and into the stream, increasing flow in the stream after an event has occurred. This modeling approach will be referred to as Model 1 for the remainder of this report.

Model 2 Representation. The second method used to represent the watershed was to treat the overland portion of the watershed as uniform, and represent the large tile drains with a series of channels that drain the low areas. Groundwater is still simulated to obtain the base flow, or the tile flow behaving as base flow, but the hydraulic conductivity of the groundwater zone is reduced. The hydraulic properties of the tile drain channel sections were adjusted to mimic pipe flow. This modeling approach will be referred to as Model 2 for the remainder of this report.

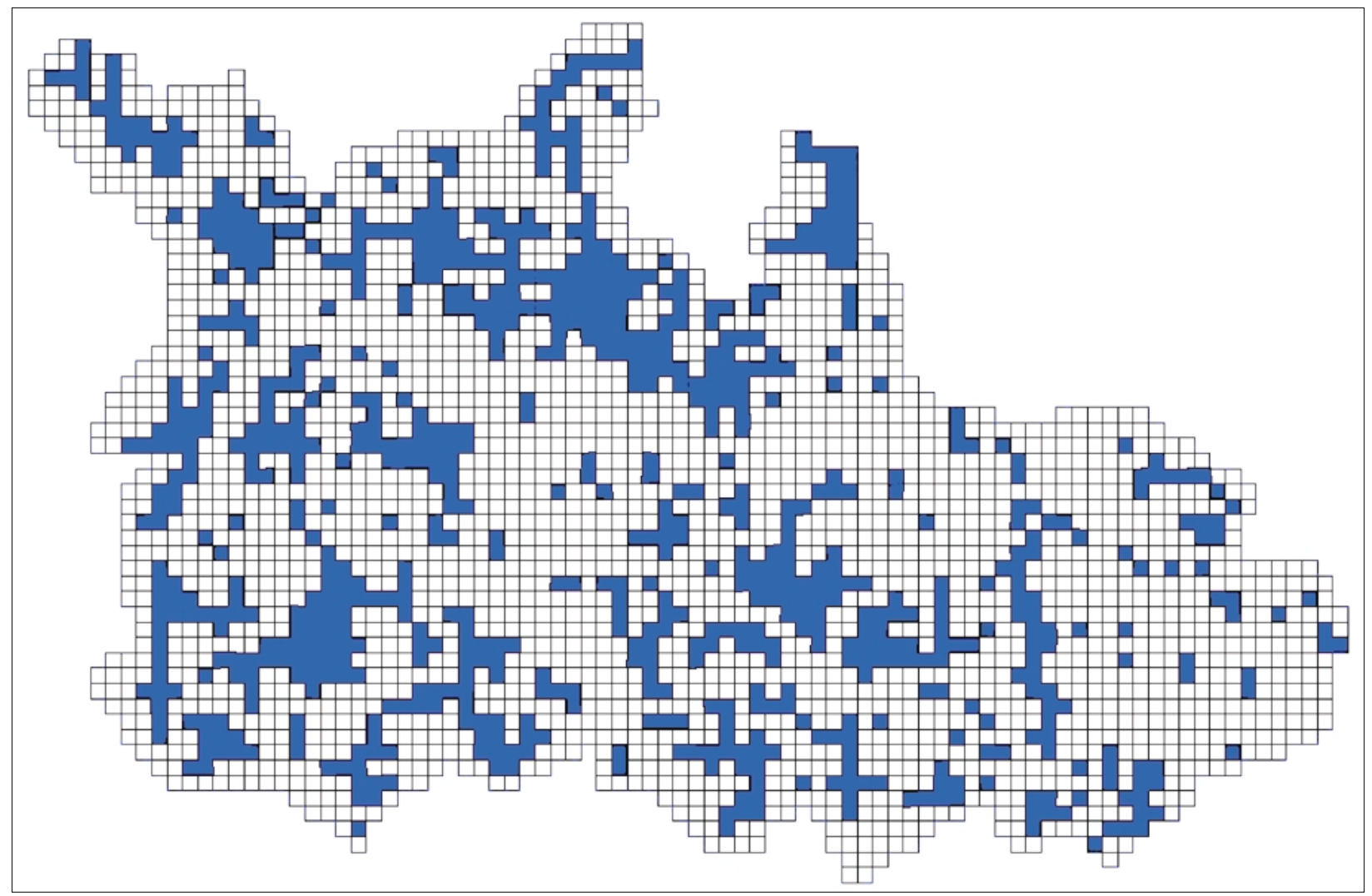

Figure 7. Location of the historical wetland areas. These areas were inferred through observations of ponding in the model 
Land use modeling considerations. Land uses of the model are based on the status of the tile drainage. Naturally drained areas were assumed to be in row crop agriculture. For Model 2 the entire basin was assumed to be row crop agriculture. For Model 1, land that didn't naturally drain was assumed to be tiled and row cropped for current conditions (Figure 7). These areas were converted back to wetlands under the restoration scenarios discussed below.

Soils modeling considerations. The active soil layer, which controls infiltration and evapotranspiration, was modeled as a single layer comprised of silty clay loam. This single soil is representative of soils in the region, which vary from silty loams to clayey loams. The hydraulic conductivity of the soil modeled varied with the land use. For the row crop areas, a hydraulic conductivity of $0.100 \mathrm{~cm} / \mathrm{hr}$ was used. In the models that utilized the hydraulic conductivity to simulate the tile drainage system, the hydraulic conductivity was set to $2.0 \mathrm{~cm} / \mathrm{hr}$ for the drained areas, and $0.025 \mathrm{~cm} / \mathrm{hr}$ for the restored areas. For the models that used a network of channels to simulate the tile drains, a uniform hydraulic conductivity of $0.100 \mathrm{~cm} / \mathrm{hr}$ was used for the entire watershed. The remaining properties for all soils were modeled as the silty clay loam, with a capillary head of $20.0 \mathrm{~cm}$, a porosity of 0.460 , a pore distribution index of 0.242 , and a residual saturation of 0.075 .

Channel modeling considerations. As discussed above, two different channel configurations were used in an attempt to model the tile drains with different methods. For both methods, the JD31 ditch was represented with trapezoidal cross sections with a side slope of 3:1. The bottom width varied from 4 to $5 \mathrm{~m}$, and the channels are incised into the landscape from 2.00 to $2.50 \mathrm{~m}$.

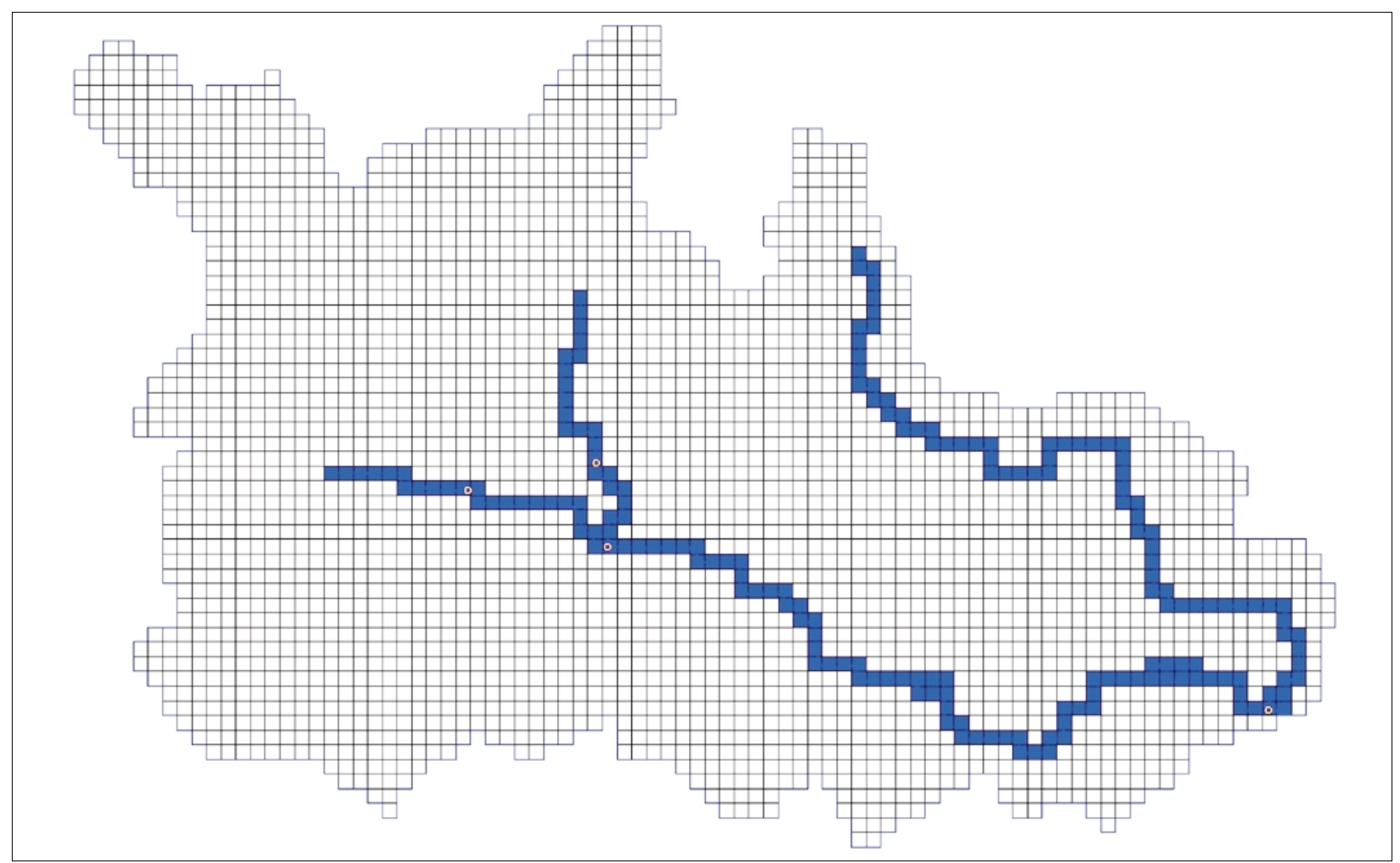

Figure 8. Model representation of the JD31 ditch network 


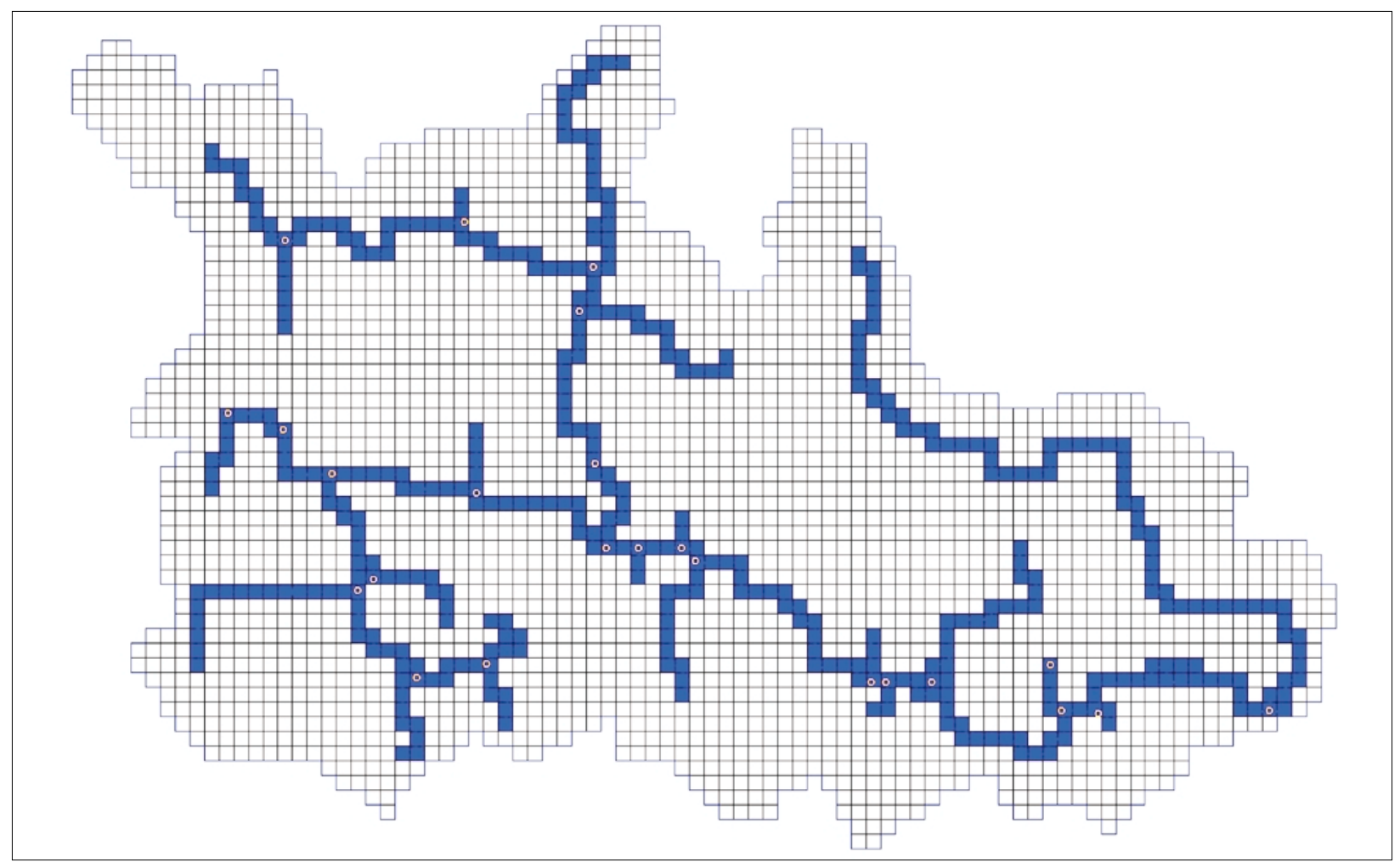

Figure 9. Model representation of the JD31 ditch and tile drain network with additional channels

This resulted in a channel network with 7 links and 196 nodes. This channel network is shown in Figure 8.

To represent the large tile drains as channels, additional channel sections were added to the channel network. The modified channels with the tile drain channel system are shown in Figure 9. The locations of these tile drain channel sections follow the original drainage as shown in Figure 3. The addition of a tile drain network resulted in a channel network containing 44 channel links with 461 nodes. These channel sections were meant to represent pipes with a $0.33-\mathrm{m}$ diameter. Each of these channel sections had the following parameters: width $-0.33 \mathrm{~m}$, side slope - vertical, Manning coefficient - 0.1.

Groundwater modeling considerations. For groundwater simulations the bottom of the aquifer was assumed to be non-porous. Approximate bedrock elevations were taken from Rodis (1963), which describes the sub-surface geology of the region in cross-sectional view. The bedrock elevations were assigned to a plane sloping toward the southeast. The bedrock elevations in the model varied between 350 and $380 \mathrm{~m}$. The sub-surface media was assumed to be homogenous glacial till. The watershed was surrounded by a no-flow boundary, and the watershed boundary was extended to the northeast to where a reasonable groundwater divide was located (Figure 5). No information was available for groundwater surface elevations in the watershed. For initial water surface elevations, information on nearby wells from the USGS NWIS Web site (National Water Information System (NWIS) 2001) was interpolated to the grid and then adjusted to maintain a depth to groundwater of at least $2 \mathrm{~m}$. This assumed starting condition was run repeatedly with June-July rainfall and hydro-meteorological data in order to produce a smooth beginning 
initial condition for the groundwater surface elevation. Stream channels in the JD31 ditch network were modeled as groundwater/stream interaction cells. Stream channels comprising the tile drain network in the extended channel network did not interact with the groundwater.

Calibration considerations. Both models (i.e., Models 1 and 2; with and without a detailed pipe network, respectively) were calibrated by manually adjusting seven model parameters. Infiltration, ET, and channel parameters were adjusted within recognized physically meaningful bounds as taken from standard references. More latitude was taken in representing features or processes that were meant to include all or part of the tile drains in addition to the explicit process description. This included the soil properties for soils in tile-drained areas, the lateral hydraulic conductivity of the saturated sub-surface media, and the hydraulic properties of channels meant to simulate larger tile drains or pipes.

The parameters listed in Table 1 were adjusted in order to obtain the best possible calibration for the models (1) without channels representing tile systems, and (2) with channels representing tile systems. If only one value is given, that value was used for both models.

\section{Table 1}

Calibration of Parameters Used in the JD31 Watershed Model ( $\mathrm{K}=$ hydraulic conductivity; $\mathrm{Ks}$ = saturated hydraulic conductivity)

\begin{tabular}{|l|c|c|c|c||}
\hline \multicolumn{1}{|c|}{ Parameter } & Initial Value & Range & Source & Final Value \\
\hline \hline Ks (cm/hr) & 0.2 & & Rawls, Brakensiek, and Miller 1983 & 0.1 \\
\hline Overland roughness & 0.35 & $0.1-0.4$ & Liong et al. 1987 0.35 \\
\hline Soil moist depth (m) & 0.4 & $0.1-1.0$ & & $(1) 0.25$ \\
\hline Channel roughness & 0.025 & $0.01-1.0$ & Chow 1959 & $(2)$ \\
\hline Pipe roughness & 0.1 & $0.05-0.5$ & & 0.3 \\
\hline K river bed (cm/hr) & 0.1 & $0.01-100$ & & 0.1 \\
\hline River bed thickness (m) & 0.1 & $0.01-1.0$ & & 0.1 \\
\hline K sub-surface (cm/hr) & 5 & $1-50$ & & 0.01 \\
\hline \hline
\end{tabular}

Calibration was conducted to get a "best" fit to the two months of data from June and July 2000. Precipitation data were recorded at the site near the JD31 outlet at 15-min intervals. Hydro-meteorological data were taken from the nearest NOAA station, located at Watertown, Minnesota. The meteorological data covered June 1, 2000 to August 31, 2000. Meteorological data were recorded hourly, and covered barometric pressure, temperature, total cloud cover, wind 
speed, and relative humidity. Data were obtained through August to ensure that the long-term simulations would have sufficient meteorological data to cover all rainfall events.

Visual comparisons to the observed flows at the JD31 outlet (Figure 2) were used to determine the best set of calibration parameters (Table 2). Factors considered in the calibration were hydrograph shape, peak heights, event volumes, and base flow. The best calibrations obtained for the two methods are presented in Figures 10 and 11.

As shown in Figures 10 and 11, both models were capable of adequately simulating small events and the base flow. The model including the detailed pipe network did a better job of simulating the larger events, especially in respect to event volumes. Watershed response for both methods shows a systematic delay that may be the result of timing problems in the recording of rainfall and flows.

Restoration Simulations. After calibration, Model 1 was used to simulate the effects of tile drain removal on surface ponding, which would correspond to wetland restoration. The same two-month period used in the calibration (June-July 2000) was used for these simulations.

Rainfall scenarios. Three rainfall scenarios were simulated for wet, dry, and normal years. To create these rainfall scenarios, the measured rainfall recorded at the site was compared to the nearest precipitation station with long-term data: Tracy, Minnesota. Data from June-July 2000 from this site were compared to the long-term average to determine the deviation from normal for the 2000 data. Total precipitation recorded at the Tracy, Minnesota, station for June and July was $61.8 \mathrm{~mm}$ and $104.6 \mathrm{~mm}$, respectively. June precipitation was $31.5 \mathrm{~mm}$ below the long-term average, while July was $13.0 \mathrm{~mm}$ above the long-term average (NCDC 2001).

June and July rainfall at the JD31 station was adjusted to normal by increasing the 15-min data by 51 percent for June and decreasing the measured rainfall amounts for July by 14 percent. The normalized precipitation values were then reduced by 33 percent to give values for a dry year, and increased by 33 percent to give values for a wet year.

The precipitation data for June includes nine rainfall events, with a maximum recorded peak of $5.59 \mathrm{~mm} / \mathrm{hr}$. In addition to the nine natural rainfall events, an artificial event was introduced on the first day of June. The first natural rainfall event occurred on the 10th of June. The artificial event produced $25.4 \mathrm{~mm}$ of rainfall in $1 \mathrm{hr}$. This artificial event was used to introduce moisture into the soils of the watershed and provide water to partially fill any low-lying areas. Starting the simulations 10 days before any rainfall events helped eliminate the effects of guessing the initial moistures in the watershed. The precipitation data for July included 11 rainfall events, with a maximum recorded peak of $7.89 \mathrm{~mm} / \mathrm{hr}$. 


\section{Table 2}

Final Parameter List and Calibration Values Used in the JD31 Watershed Model (Ks = saturated hydraulic conductivity; Veg. = Vegetation; Rad = radiation)

\begin{tabular}{|c|c|c|c|}
\hline Process & Parameter Description & Units & Value \\
\hline Infiltration & Ks - crops/clay loam & $\mathrm{cm} / \mathrm{hr}$ & 0.1 \\
\hline Infiltration & Ks - tile-drained areas & $\mathrm{cm} / \mathrm{hr}$ & 2.0 \\
\hline Infiltration & Ks - restored wetlands/clay loam & $\mathrm{cm} / \mathrm{hr}$ & 0.025 \\
\hline Infiltration & Suction head - clay loam & $\mathrm{cm}$ & 20.0 \\
\hline Infiltration & Porosity - clay loam & & 0.46 \\
\hline Infiltration & Initial moisture - crops & & 0.25 \\
\hline Infiltration & Initial moisture - wetlands & & 0.40 \\
\hline Overland flow & Manning $\mathrm{n}$ - crops, Model 1 & & 0.35 \\
\hline Overland flow & Manning $\mathrm{n}$ - crops, Model 2 & & 0.25 \\
\hline Infiltration/ET & Port dist. Index - clay loam & & 0.242 \\
\hline Infiltration/ET & Residual saturation - clay loam & & 0.075 \\
\hline Infiltration/ET & Wilting point - clay loam & & 0.197 \\
\hline ET & Albedo - crops, clay loam & & 0.2 \\
\hline ET & Albedo - wetlands, clay loam & & 0.2 \\
\hline ET & Veg. Height - crops & $\mathrm{m}$ & 1.0 \\
\hline ET & Veg. Height - wetlands & $\mathrm{m}$ & 0.33 \\
\hline ET & Veg. Rad. Coefficient - crops & & 0.20 \\
\hline ET & Veg. Rad. Coefficient - wetlands & & 0.40 \\
\hline ET & Canopy resistance - crops & $\mathrm{s} / \mathrm{m}$ & 20.0 \\
\hline ET & Canopy resistance - wetlands & $\mathrm{s} / \mathrm{m}$ & 100.0 \\
\hline Soil moisture & Root zone depth - Model 1 & $\mathrm{~m}$ & 0.40 \\
\hline Soil moisture & Root zone depth - Model 2 & $\mathrm{~m}$ & 0.30 \\
\hline Channel flow & Manning's $\mathrm{n}$ - ditch & & 0.025 \\
\hline Channel flow & Manning's $n$ - pipes & & 0.1 \\
\hline Groundwater & Porosity & & 0.46 \\
\hline Groundwater & Hydraulic conductivity & $\mathrm{cm} / \mathrm{hr}$ & 15.0 \\
\hline Groundwater/channels & $\mathrm{K}$ stream bed & $\mathrm{cm} / \mathrm{hr}$ & 0.1 \\
\hline Groundwater/channels & Stream bed thickness - Model 1 & $\mathrm{~m}$ & 0.02 \\
\hline Groundwater/channels & Stream bed thickness - Model 2 & $\mathrm{~m}$ & 0.01 \\
\hline
\end{tabular}




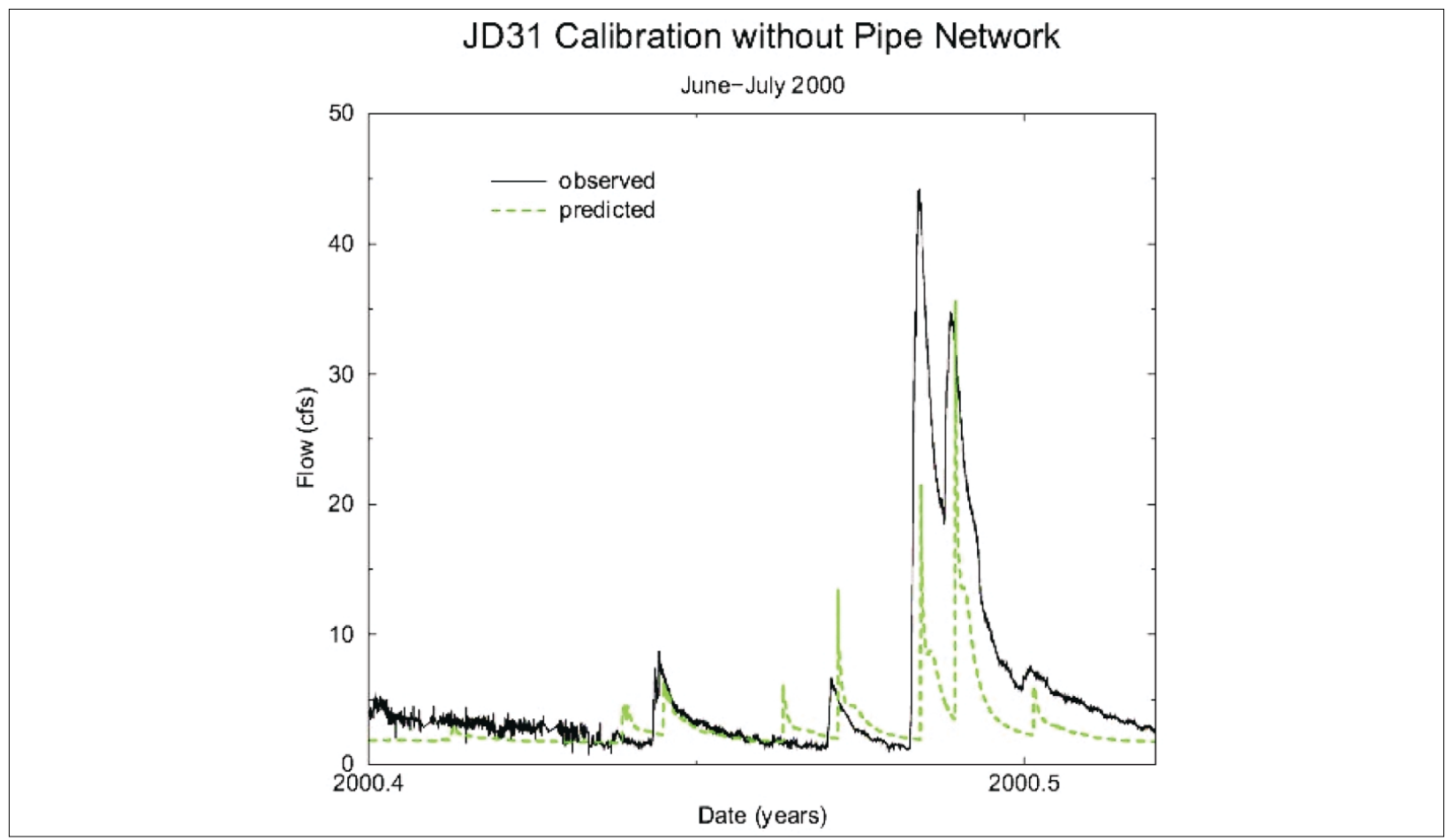

Figure 10. Flow from the JD31 calibrated model using differing soil hydraulic conductivities without the tile (pipe) network versus measured flows between June and July 2000 (i.e., Model 2, see text)

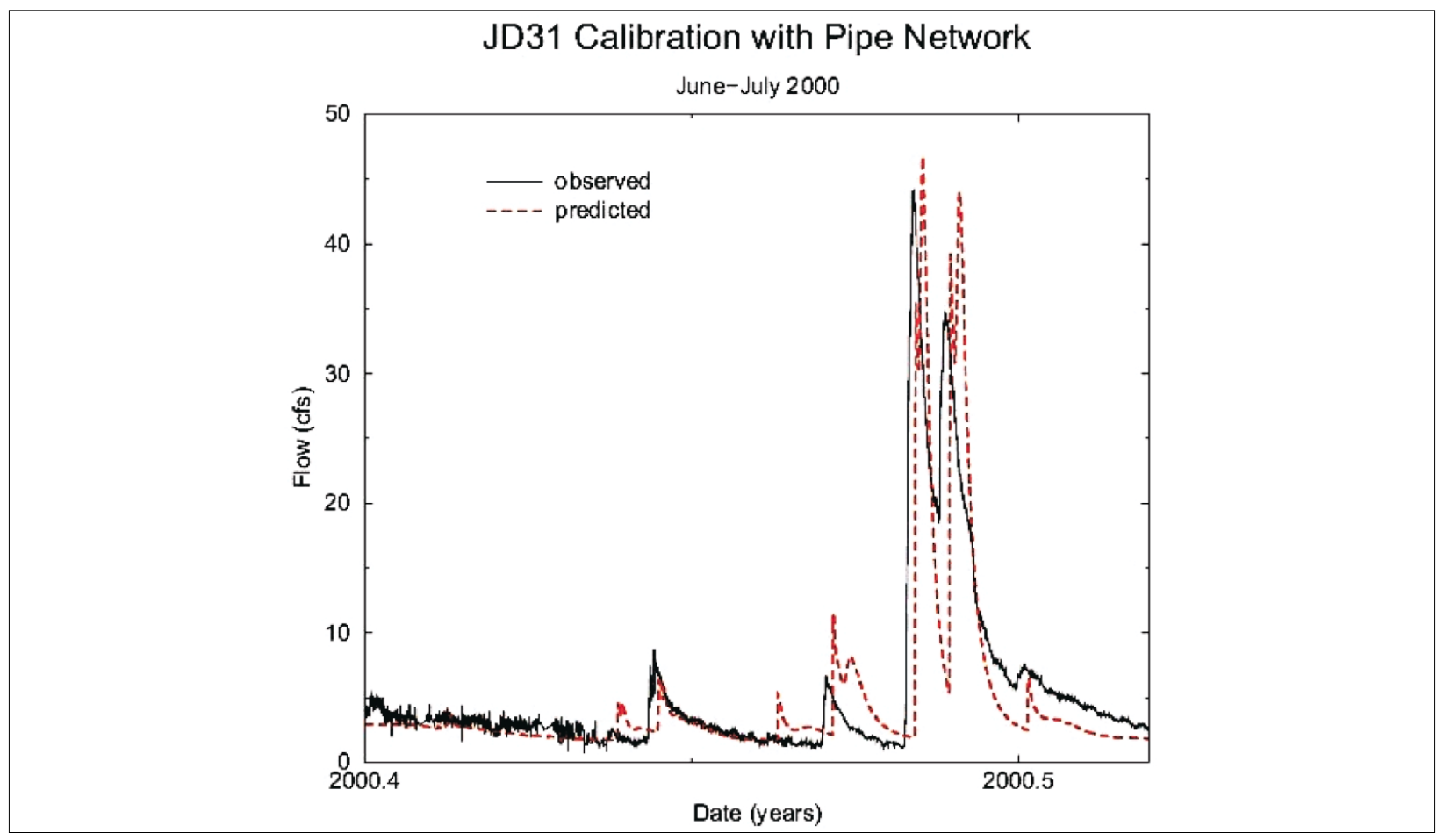

Figure 11. Flow from the JD31 calibrated model using differing soil hydraulic conductivities with the tile (pipe) network versus measured flows between June and July 2000 (i.e., Model 2, see text) 


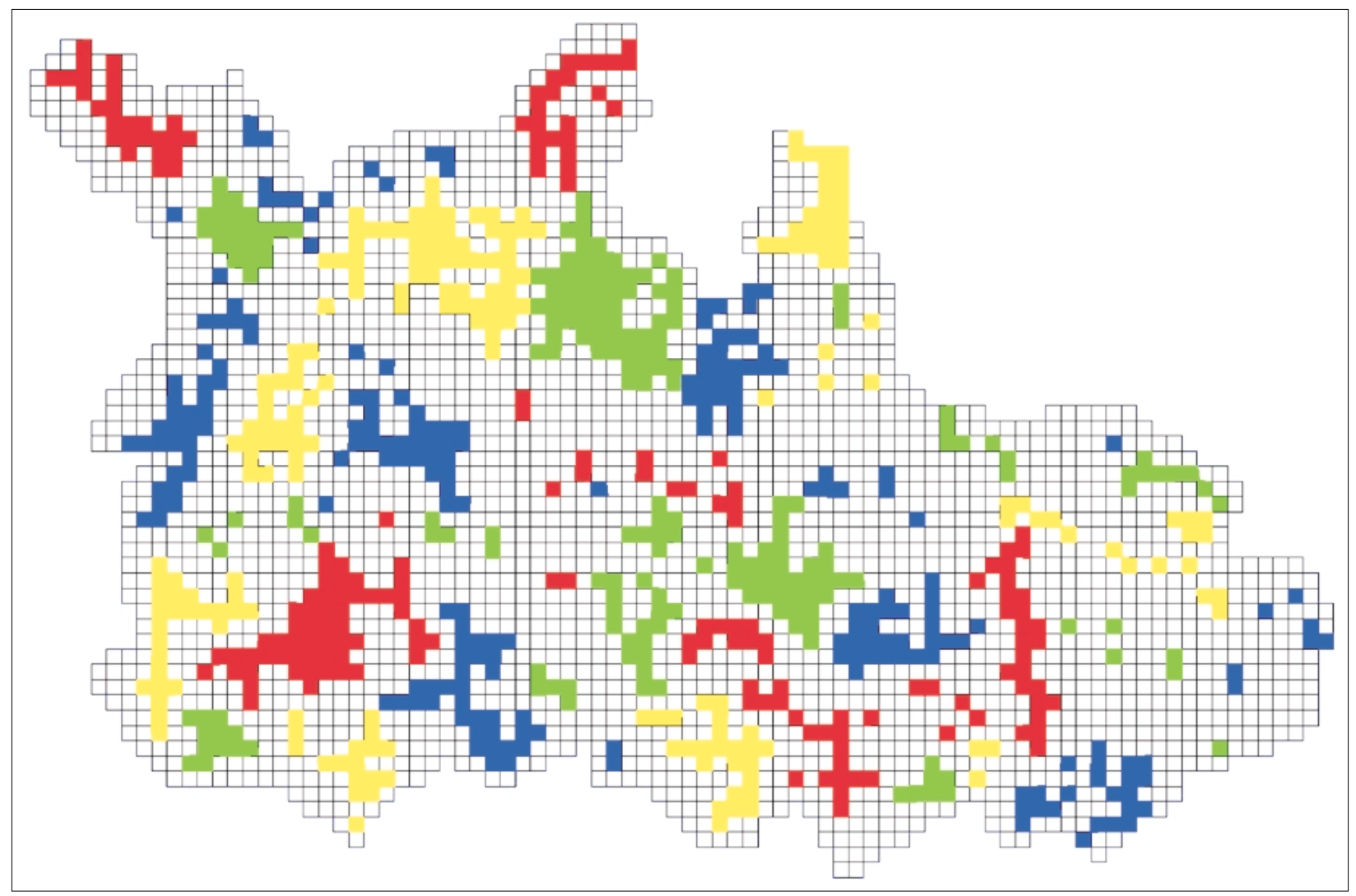

Figure 12. Division of the wetland areas in JD31 into four groups

Restoration scenarios. Restoration scenarios were created by subdividing the tile-drained areas, shown in Figure 6, into four distinct regions, shown in Figure 12. The divisions each had larger areas $\left(>250,000 \mathrm{~m}^{2}\right)$ to smaller areas $\left(<81,000 \mathrm{~m}^{2}\right)$, with the largest unit being approximately $500,000 \mathrm{~m}^{2}$ and the smallest unit being $8,100 \mathrm{~m}^{2}$, or one grid cell. The large and small areas were divided as evenly as possible into the four groups, with each soil group being distributed as evenly as possible over the watershed. For this distribution, it was assumed that hydraulically connected areas would be restored as one unit and that the restored areas would not be grouped together but spread out evenly across the watershed. This division allowed for simulations of the current conditions and restoration of 25, 50, 75, and 100 percent of the wetlands. The five different wetland restoration scenarios, each run under three different precipitation conditions, yield a total of 15 simulations.

Tile-drained areas were restored by changing the parameters in the cells corresponding to the restored areas. Parameters were changed from the tile-drained set of parameters to the restored set of parameters as listed in Table 2. In general, changing from a tile-drained area to a wetland area entailed lowering the hydraulic conductivity of the soil and changing the vegetation characteristic from that of a row crop to that of wetland grasses/sedges. For this simulation, it was assumed that the restored areas would eventually have a lower value of hydraulic conductivity than the surrounding agricultural areas due to sedimentation and compaction of fines.

RESULTS: Figure 13 shows snapshots of water depth on the overland flow plane for each restoration level. These figures correspond to the "normal" rainfall scenario illustrating before, 


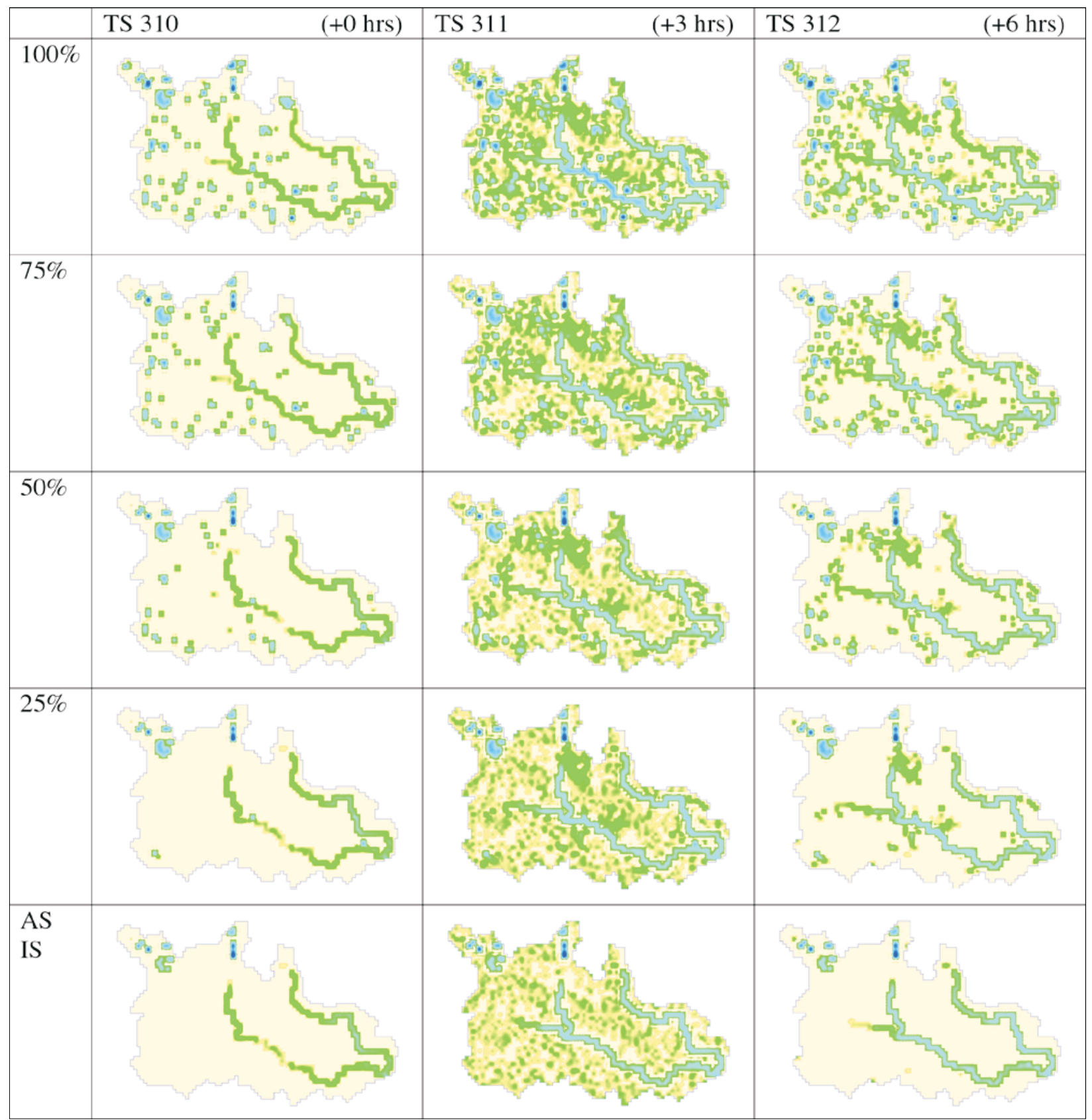

Figure 13. Variations in overland flow depth (green and blue areas) for different wetland restoration scenarios for time-step (TS) 310 through TS 312. AS IS = current conditions; $25 \%=25$ percent wetland restoration; $50 \%=50$ percent wetland restoration; $75 \%=75$ percent wetland restoration; $100 \%=100$ percent wetland restoration

during, and after storm event conditions. Dark areas correspond to ponded water. The darker the shade, the deeper the ponding. A precipitation event occurred between TS (time-step) 310 and TS 311, resulting in the overland flow plane depths seen in TS 311. TS 311 and TS 312 show the differences in the rates of response after the same precipitation event has occurred at each of the simulations. 
A gradual procession from dry to wet conditions occurred from the current watershed conditions to the 100-percent restoration conditions (Figure 13). The first set of snapshots, TS 310, shows the pre-storm conditions. For the current conditions, water was confined to stream channels and a few ponded areas. For the 100-percent restoration conditions, many small wetland areas existed. During a rainfall event, TS 311, all scenarios had water ponded on the watershed. However, the restored areas had significantly deeper ponding. The last of the snapshots, TS 312 , shows the water depth conditions just a few hours after the storm event. As shown in the figure, the current conditions rapidly returned to the pre-storm levels, indicating rapid drainage of ponded water via the tile network. In contrast, the restored areas were still ponding significant water over the same time period.

This series of snapshots demonstrated that the restored wetland areas ponded deeper water during storm events and retained this water much longer after the storm event ended, resulting in small wetland areas existing throughout the summer season. These areas also maintained higher soil moistures. Animated graphics of the model results can be found in Appendix A. In the animations, ponded areas appear as greens and blues. Green corresponds to shallow ponding. Blue corresponds to deeper areas. The darker the blue, the deeper the ponding.

CONCLUSIONS: The JD31 watershed is a highly disturbed watershed that is comprised of several smaller watersheds that are not naturally part of the same watershed. This watershed was created by draining the encompassed area with a large uniform ditch, JD31, and a system of sub-surface tile drainage networks. Flows to the JD31 ditch are thought to result from a combination of overland flow, groundwater discharge to the stream, and tile drainage to the stream. Because of the complexity of the processes that generate flow, it was difficult to simulate the hydrologic response with numerical models.

For this study the multi-dimensional, physically based, hydrologic model GSSHA was selected to model the watershed. Earlier attempts to apply other models in similar basins in the watershed, such as $C A S C 2 D$ in Clear Creek, had produced poor results because the model did not include many of the important processes that generate stream flow. The GSSHA model was selected because it had the ability to simulate surface flows, sub-surface flows, and stream/groundwater interaction on a single event and long-term basis.

The GSSHA model was modified to use the GAR estimates of infiltration as groundwater recharge values. The GSSHA code was modified such that the GAR method provided continuous recharge values to the groundwater code. The modified code was used to model the basin for the period of June-July 2000, when good field data were available for calibration.

Because the GSSHA model did not explicitly account for tile drains, other processes contained in the code were used to simulate the effect of the tile drain network. Two models were created. Model 1 attempted to simulate the effect of the tile drains through modified parameter values for infiltration and groundwater recharge. This model proved useful for simulating overland flow depths and ponding of water with restoration scenarios. Model 2 simulated the effect of the tile drains with the inclusion of a vast network of channels representing the actual tiles. This model proved more capable of simulating larger flow events, especially the storm volumes. The two models were calibrated against the June-July data through the adjustment of parameters in the 
models. Both models did a good job of representing base flow and the stream response for smaller rainfall events. Model 2 did a better job of simulating larger events, especially the event volumes.

Model 1 was used to simulate the effect of restoration of wetlands in the watershed as percent restoration of tile-drained areas. This semi-quantitative analysis indicated that significant ponding on the watershed could result if removal of tile drains in selected areas would proceed. The ponding of this water should result in lower peak discharges and lower sediment loads in the stream, and could provide some temporary habitat, as seasonal wetlands should result from these restoration efforts.

Both models can be used to simulate different BMPs in the watershed. Model 1 is probably best suited for analyzing ponding on the surface due to restorations and BMPs. Model 2 is probably better suited for providing detailed flow information at various points in the system, and can provide approximate flows from the tile drains into the stream. This model could be used to analyze the effects of reduced flows to the stream if parts of the tile drain system would be dismantled.

ACKNOWLEDGMENTS: This research was funded by the Water Operations Technical Support (WOTS) Program.

POINTS OF CONTACT: This technical note was written by Dr. Charles W. Downer of the Coastal and Hydraulics Laboratory (CHL), Engineer Research and Development Center (ERDC); Mr. William F. James of the Eau Galle Aquatic Ecology Laboratory, Environmental Laboratory (EL), ERDC; Mr. Aaron Byrd of Brigham Young University; and Mr. Gregory W. Eggers of the U.S. Army Engineer District, St. Paul, Army Corps of Engineers Centre. For additional information, contact the managers of the Water Operations Technical Support (WOTS) Program, Dr. John W. Barko (601-634-3654,John.W.Barko@erdc.usace.army.mil) or Mr. Robert C. Gunkel (601-634-3722, Robert.C.Gunkel@erdc.usace.army.mil). This technical note should be cited as follows:

Downer, C. W., James, W. F., Byrd, A., and Eggers, G. W. (2002). “Gridded surface subsurface hydrologic analysis (GSSHA) model simulation of hydrologic conditions and restoration scenarios for the Judicial Ditch 31 Watershed, Minnesota," Water Quality Technical Notes Collection (ERDC WQTN-AM-12), U.S. Army Engineer Research and Development Center, Vicksburg, MS.

\section{REFERENCES}

Chow, V. T. (1959). Open channel hydraulics. McGraw Hill, New York.

Downer, C. W., and Ogden, F. L. "Gridded Surface Subsurface Hydrologic Analysis Users Manual,” in preparation, U.S. Army Engineer Research and Development Center, Vicksburg, MS.

Hokanson, H. L. (1978). "Soil survey of Lyon County, Minnesota," United States Department of Agriculture, Washington, DC.

Hokanson, H. L., Anderson, W. W., Calkins, D. W., Hein, K. W., Lorenzen, F. D., Murray, J. J., Paulson, R. O., and Peterson, R. F. (1970). "Soil survey of Lincoln County, Minnesota," United States Department of Agriculture, Washington, DC. 
ISCO, Inc. (1997-98). "FlowLink4 for Windows: Version 4.01,” (computer program), Lincoln, NE.

James, W. F., Barko, J. W., Eakin, H. L., and Eggers, G. W. (2001). "Loading of biologically available constituents from an agricultural subwatershed in the Redwood River Basin, Minnesota," Water Quality Technical Notes Collection (ERDC WQTN-PD-10), U.S. Army Engineer Research and Development Center, Vicksburg, MS.

Loing, S. Y., Selvalingam, S., and Brady, D. K. (1989). "Roughness values for overland flow in subcatchments," J. Irrigation and Drainage Engineering 115 (2): 203-215.

National Atlas of the United States of America. "Image of Minnesota with counties and surrounding states," United States Department of the Interior, The National Atlas of the United States of America, http://nationalatlas.gov/natlas/natlasstart.asp, August 14, 2001.

National Climatic Data Center. (NCDC). (2001). “Annual Climatological Summary (2000): Tracy, Minnesota.” National Climatic Data Center, http://lwf.ncdc.noaa.gov/servelets/ACS, July 17, 2001.

National Water Information System (NWIS). (2001). "Ground water for USA: Water Levels, by Lat-Lon Box, Latitude $44^{\circ} 18^{\prime} 0^{\prime \prime}$ to $44^{\circ} 15^{\prime} 0^{\prime}$, Longitude $96^{\circ} 7^{\prime} 30^{\prime \prime}$ to $96^{\circ} 0^{\prime} 0^{\prime \prime}$." NWISWeb, United States Geological Survey, Department of the Interior, http://water.usgs.gov/nwis/gwlevels.

Nelson, E. J. (2001). “WMS V6.1 HTML Help Document,” Environmental Modeling Research Laboratory, Brigham Young University, Provo, UT.

Ogden, F. L. (1998). “CASC2D, Version 1.18 Reference Manual,” Dept. of Civil and Environmental Engineering, U-37, University of Connecticut, Storrs.

Ogden, F. L., and Saghafian, B. (1997). “Green and ampt infiltration with redistribution,” J. Irrigation and Drainage Engineering, 123, 386-393.

Paulson, J., and Philippi, N. (1998). "Wetlands Initiative." www.wetlands-initiative.org/pub/redwood.html.

Rawls, W. J., Brakensiek, D. L., and Miller, N. (1983). "Green-Ampt infiltration parameters from soils data," J. Hydraulic Engineering 109(1), 62-71.

Rodis, H. G. (1963). “Geology and occurrence of groundwater in Lyon County, Minnesota," U.S. Geological Survey, Supply Paper 1619-N, U.S. Government Printing Office, Washington, DC.

Senarath, U. S., Ogden, F. L., Downer, C. W., and Sharif, H. O. (2000). "On the calibration and verification of two-dimensional, distributed, Hortonian, continuous watershed models," Water Resources Research, 36(6), 1495-1510.

Vicksburg Post. (2001). “Biggest dead zone ever looms in Gulf of Mexico.” Vicksburg Post, July 27, 2001.

NOTE: The contents of this technical note are not to be used for advertising, publication, or promotional purposes. Citation of trade names does not constitute an official endorsement or approval of the use of such products. 


\section{Appendix A}

Material Properties of a Selection of Common and Uncommon Soils Found in the Coon Creek Area (Table Reproduced from Hokanson (1978))

\begin{tabular}{|c|c|c|c|c|}
\hline Name & Depth & $\begin{array}{c}\text { Permeability } \\
\text { In/Hr }\end{array}$ & $\begin{array}{c}\text { Available water } \\
\text { capacity } \\
\text { In/ln }\end{array}$ & Unified Classification \\
\hline \multicolumn{5}{|c|}{ Barnes Loam (common) } \\
\hline \multirow[t]{3}{*}{ Barnes } & $0-11 "$ & $0.6-2.0$ & $0.13-0.24$ & CL, CL-ML \\
\hline & $11-16 "$ & $0.6-2.0$ & $0.15-0.19$ & $\mathrm{CL}, \mathrm{CL}-\mathrm{ML}$ \\
\hline & $16-60 "$ & $0.6-2.0$ & $0.14-0.19$ & $\mathrm{CL}, \mathrm{CL}-\mathrm{ML}$ \\
\hline \multicolumn{5}{|c|}{ Flom Clay Loam (common) } \\
\hline \multirow[t]{3}{*}{ Flom } & $0-20 "$ & $0.2-2.0$ & $0.17-0.24$ & OL, CL-ML, CL \\
\hline & 20-39" & $0.2-0.6$ & $0.15-0.19$ & $\mathrm{CL}$ \\
\hline & $39-60 "$ & $0.2-0.6$ & $0.14-0.19$ & $\mathrm{CL}$ \\
\hline \multicolumn{5}{|c|}{ Sinai Silty Clay (common) } \\
\hline \multirow[t]{3}{*}{ Sinai } & 0-33" & $0.06-0.20$ & $0.13-0.16$ & $\mathrm{CL}, \mathrm{CH}, \mathrm{MH}$ \\
\hline & $33-47^{\prime \prime}$ & $0.06-0.20$ & $0.11-0.17$ & $\mathrm{CL}, \mathrm{CH}, \mathrm{MH}$ \\
\hline & $47-60 "$ & $0.06-0.20$ & $0.11-0.17$ & $\mathrm{CL}, \mathrm{CH}$ \\
\hline \multicolumn{5}{|c|}{ Svea Loam (common) } \\
\hline \multirow[t]{3}{*}{ Svea } & $0-21 "$ & $0.6-2.0$ & $0.20-0.24$ & $\mathrm{CL}, \mathrm{CL}-\mathrm{ML}$ \\
\hline & 21-31" & $0.6-2.0$ & $0.17-0.22$ & $\mathrm{CL}, \mathrm{CL}-\mathrm{ML}$ \\
\hline & $31-60 "$ & $0.6-2.0$ & $0.14-0.19$ & $\mathrm{CL}, \mathrm{CL}-\mathrm{ML}$ \\
\hline \multicolumn{5}{|c|}{ Poinsett Silty Clay Loam (common) } \\
\hline \multirow[t]{3}{*}{ Poinsett } & $0-11 "$ & $0.6-2.0$ & $0.19-0.22$ & $\mathrm{CL}, \mathrm{ML}$ \\
\hline & $11-30 "$ & $0.6-2.0$ & $0.18-0.21$ & $\mathrm{CL}$ \\
\hline & $30-60 "$ & $0.6-2.0$ & $0.12-0.20$ & CL, ML, SC, SM-SC \\
\hline \multicolumn{5}{|c|}{ Buse-Sioux Complex (uncommon) } \\
\hline \multirow[t]{2}{*}{ Buse } & $0-7 "$ & $0.6-2.0$ & $0.17-0.22$ & $\mathrm{ML}, \mathrm{CL}, \mathrm{CL}-\mathrm{ML}$ \\
\hline & $7-60 "$ & $0.6-2.0$ & $0.14-0.19$ & $\mathrm{CL}, \mathrm{CL}-\mathrm{ML}$ \\
\hline \multirow[t]{2}{*}{ Sioux } & $0-7 "$ & $0.6-6.0$ & $0.10-0.20$ & SM, SC, ML, CL \\
\hline & $7-60 "$ & $6.0-20$ & $0.03-0.06$ & $\mathrm{GM}, \mathrm{GP}, \mathrm{SM}, \mathrm{SP}$ \\
\hline \multicolumn{5}{|c|}{ Arvilla - Barnes - Buse Complex (uncommon) } \\
\hline \multirow[t]{3}{*}{ Arvilla } & $0-6 "$ & $2.0-6.0$ & $0.13-0.15$ & SM, SC, SM-SC \\
\hline & $6-16 "$ & $2.0-6.0$ & $0.13-0.15$ & SM, SC, SM-SC \\
\hline & $16-60 "$ & $>6.0$ & $0.02-0.05$ & SP-SM, GP, SP, GP-GM \\
\hline \multirow[t]{3}{*}{ Barnes } & $0-7 "$ & $0.6-2.0$ & $0.13-0.24$ & $\mathrm{CL}, \mathrm{CL}-\mathrm{ML}$ \\
\hline & $7-12 "$ & $0.6-2.0$ & $0.15-0.19$ & $\mathrm{CL}, \mathrm{CL}-\mathrm{ML}$ \\
\hline & $12-60 "$ & $0.6-2.0$ & $0.14-0.19$ & $\mathrm{CL}, \mathrm{CL}-\mathrm{ML}$ \\
\hline \multirow[t]{2}{*}{ Buse } & $0-7 "$ & $0.6-2.0$ & $0.17-0.22$ & $\mathrm{ML}, \mathrm{CL}, \mathrm{ML}-\mathrm{CL}$ \\
\hline & $7-60 "$ & $0.6-2.0$ & $0.14-0.19$ & $\mathrm{CL}, \mathrm{CL}-\mathrm{ML}$ \\
\hline
\end{tabular}


ERDC WQTN-AM-12

June 2002
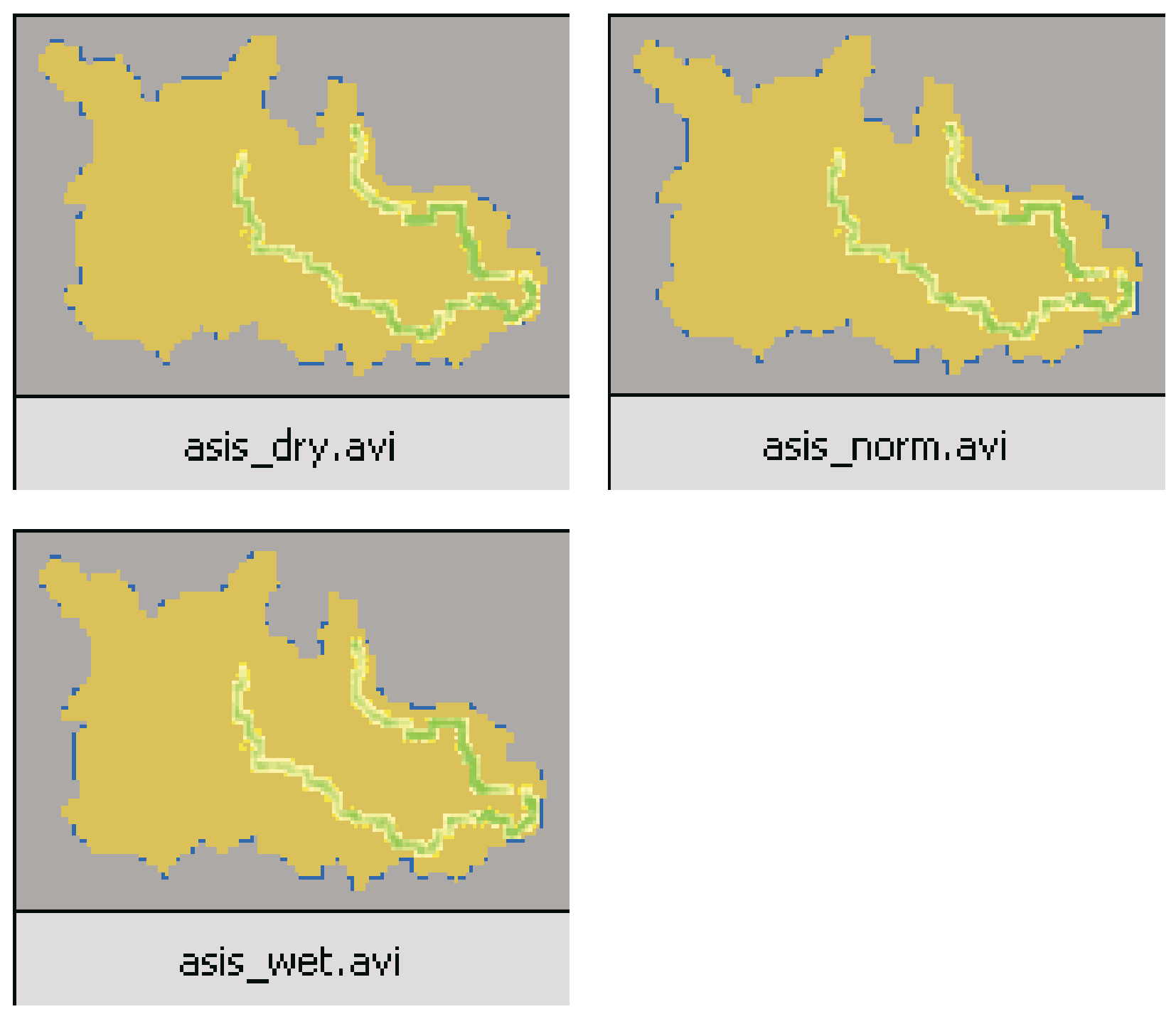

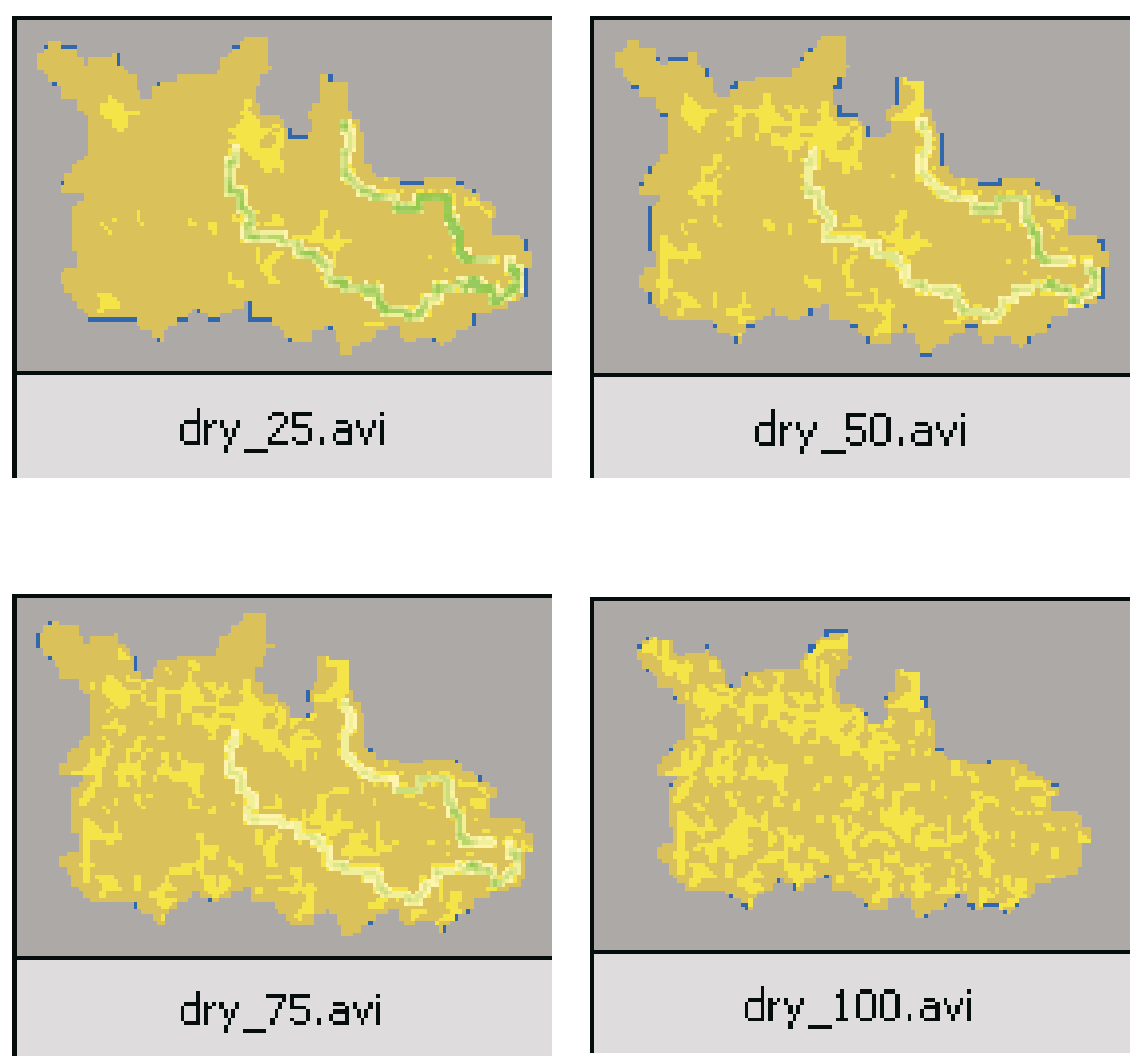
ERDC WQTN-AM-12

June 2002
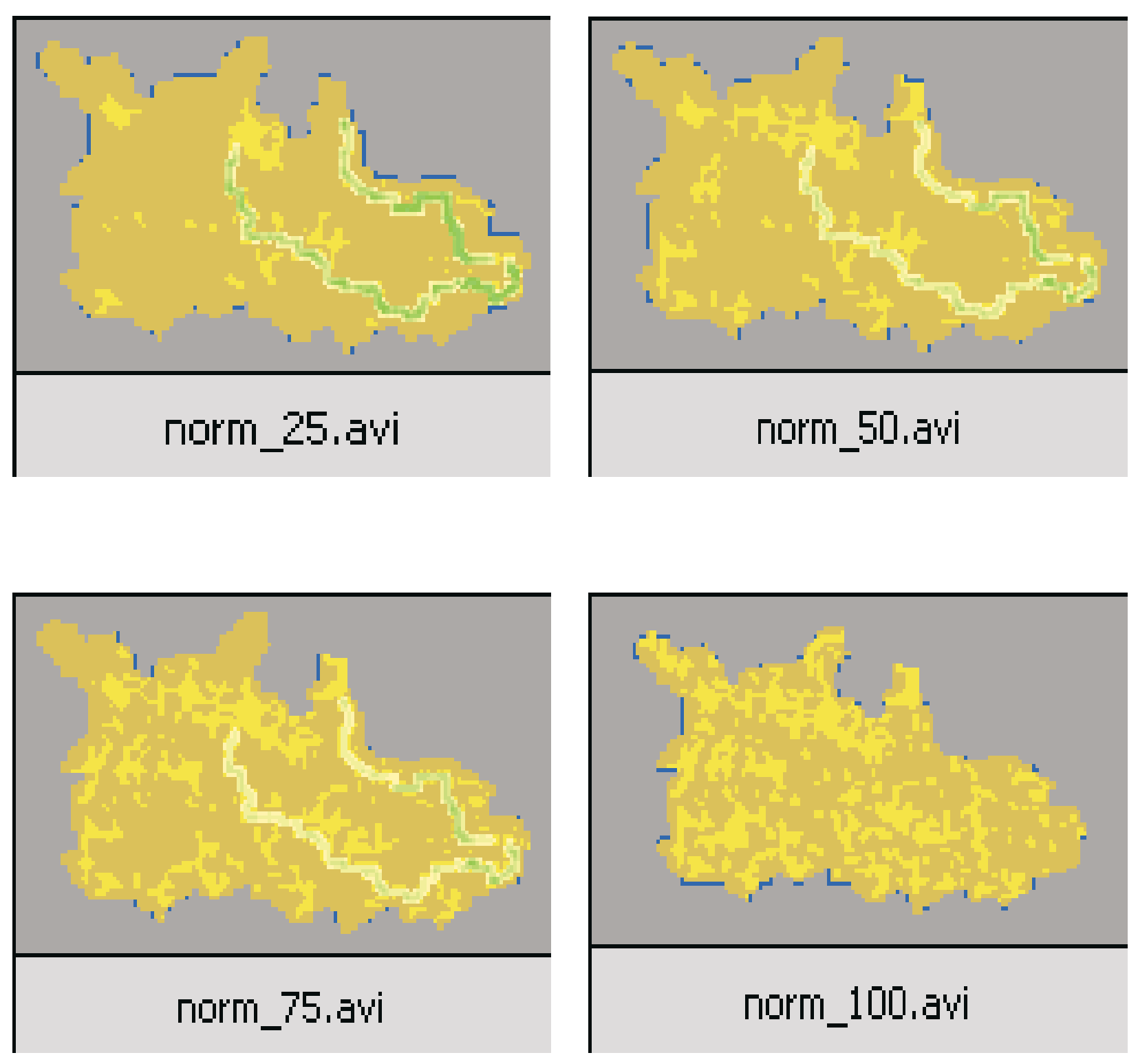

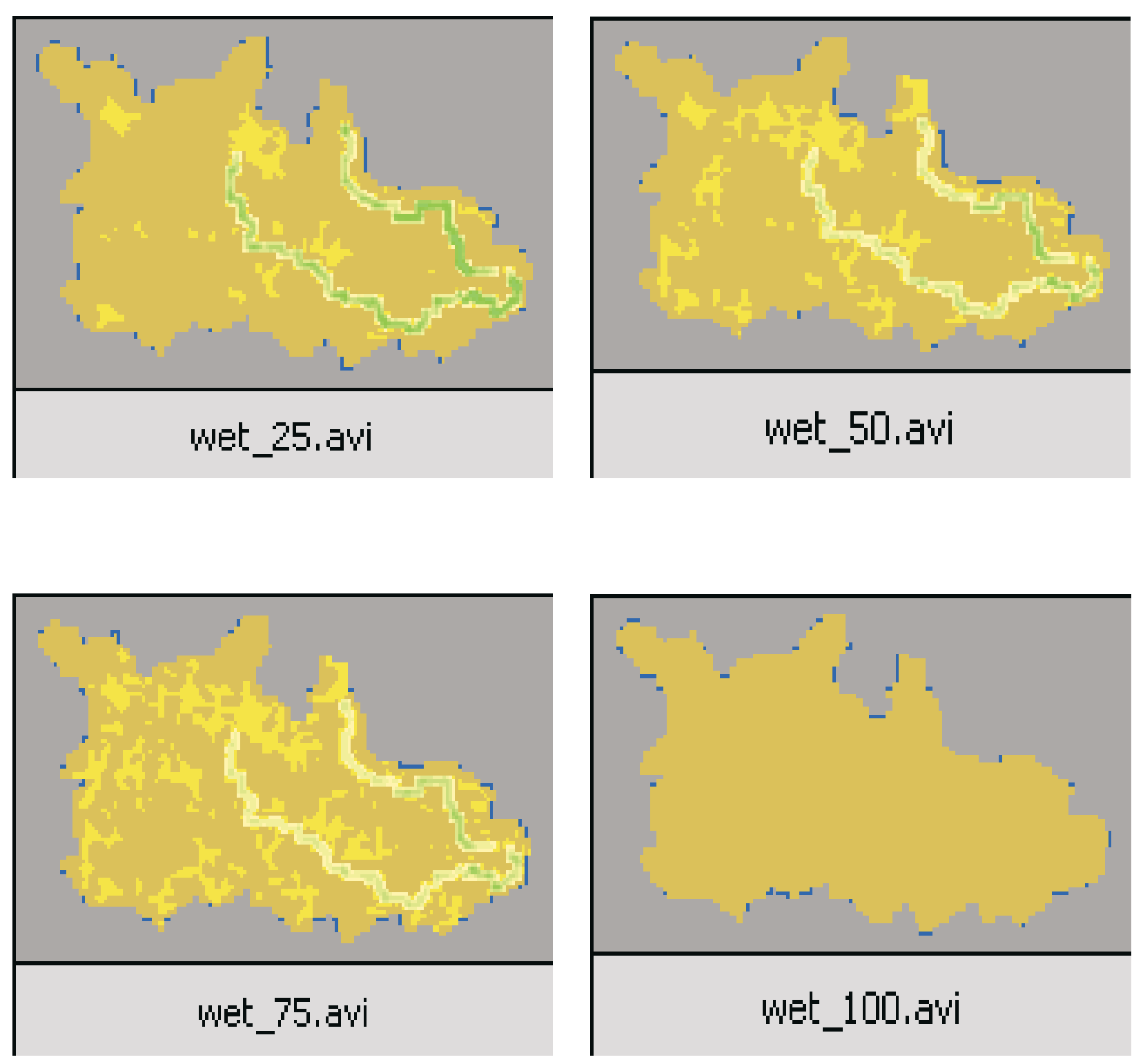